\title{
US Nicotine Vaping Product SimSmoke Simulation Model: The Effect of Vaping and Tobacco Control Policies on Smoking Prevalence and Smoking-Attributable Deaths
}

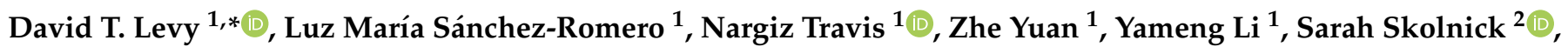 \\ Jihyoun Jeon ${ }^{2}\left(\mathbb{D}\right.$, Jamie Tam ${ }^{3}\left(\mathbb{D}\right.$ and Rafael Meza ${ }^{2} \mathbb{}$ \\ 1 Lombardi Comprehensive Cancer Center, Georgetown University, Washington, DC 20007, USA; \\ 1s1364@georgetown.edu (L.M.S.-R.); nt526@georgetown.edu (N.T.); zy70@georgetown.edu (Z.Y.); \\ y1954@georgetown.edu (Y.L.) \\ 2 Department of Epidemiology, University of Michigan, Ann Arbor, MI 48109, USA; srskol@umich.edu (S.S.); \\ jihjeon@umich.edu (J.J.); rmeza@umich.edu (R.M.) \\ 3 Department of Health Policy and Management, Yale University School of Public Health, \\ Hartford, CT 06520, USA; jamie.tam@yale.edu \\ * Correspondence: dl777@georgetown.edu
}

Citation: Levy, D.T.;

Sánchez-Romero, L.M.; Travis, N.; Yuan, Z.; Li, Y.; Skolnick, S.; Jeon, J.; Tam, J.; Meza, R. US Nicotine Vaping Product SimSmoke Simulation Model: The Effect of Vaping and Tobacco Control Policies on Smoking Prevalence and Smoking-Attributable Deaths. Int. J. Environ. Res. Public Health 2021, 18, 4876. https:// doi.org/10.3390/ijerph18094876

Academic Editor: Jimmy T. Efird

Received: 12 March 2021

Accepted: 26 April 2021

Published: 3 May 2021

Publisher's Note: MDPI stays neutral with regard to jurisdictional claims in published maps and institutional affiliations.

Copyright: (c) 2021 by the authors. Licensee MDPI, Basel, Switzerland. This article is an open access article distributed under the terms and conditions of the Creative Commons Attribution (CC BY) license (https:/ / creativecommons.org/licenses/by/ $4.0 /)$.

\begin{abstract}
The public health impact of nicotine vaping products (NVPs) is subject to a complex set of uncertain transitions between NVP and cigarette use. Instead, we apply an indirect method to gauge the impact of NVP use on smoking prevalence and smoking-attributable deaths (SADs) using the well-established SimSmoke tobacco control policy simulation model. Upon validating the model before NVPs were more widely used, we project a No-NVP (i.e., in the absence of NVPs) while controlling for the impact of cigarette-oriented policies. The net impact of NVPs on smoking prevalence is inferred by comparing the projected No-NVP smoking trends to corresponding trends from two US national surveys. Using the TUS-CPS estimates for the period 2012-2018, we estimate that adult smoking prevalence declined in relative terms by $9.7 \%$ (95\% CI: $7.5-11.7 \%$ ) for males and $10.7 \%$ (95\% CI: $9.1-13.0 \%$ ) for females. Compared to NHIS, smoking prevalence declined by 10.7\% (95\% CI: 6.8-14.6\%) for males and 11.3\% (95\% CI: 7.4-15.6\%) for females. These impacts were confined mainly to ages 18-44. Vaping-related reductions in smoking prevalence were projected to avert nearly 0.4 million SADs between 2012 and 2052. Our analysis indicates that NVP use is associated with substantial reductions in US smoking prevalence among younger adults.
\end{abstract}

Keywords: smoking; cigarettes; e-cigarettes; ENDS; vaping; tobacco control; simulation model; public health

\section{Introduction}

Since the Surgeon General's Report in 1964, smoking prevalence has declined by more than $50 \%$ in the US [1,2]. Simulation models show that much of this reduction can be explained by smoking tobacco control policies [1-5], especially increased cigarette taxes, smoke-free air policies, media campaigns, restrictions on youth access to tobacco, and cessation treatment policies [1,6]. While simulation models project that US smoking prevalence will continue to decline under current policies [3,7-11], they also indicate that prevalence will not drop below $10 \%$ for at least another two decades. That trajectory may change now that NVPs are more widely used. As a country with relatively unrestrictive policies $[12,13]$, the US provides a case study of the potential impact of NVPs on smoking.

NVPs represent a new generation of nicotine delivery products, which have become progressively more efficient in delivering nicotine to the user [14-16]. Studies indicate that NVP use has enabled smokers to quit smoking [17-21] and has replaced cigarette smoking among some youth and young adults [22-24]. Other studies suggest that NVP use may lead to youth cigarette smoking $[25,26]$, inhibit smoking cessation $[27,28]$ and promote 
relapse $[29,30]$. Predicting the impact of NVPs on smoking prevalence depends on the ability to accurately incorporate transitions between NVP use and smoking [31]. However, that data are often limited and, as a disruptive technology [32,33], NVP use and associated transitions may be unstable.

Rather than explicitly modeling the impact of NVPs on smoking prevalence, we apply an indirect method that does not require information on smoking and NVP use transitions. We first develop a No-NVP scenario, which represents smoking behavior assuming the absence of NVPs. To obtain the No-NVP scenario, we adapt the well-established and previously validated US SimSmoke tobacco control policy simulation model $[3,7,34]$, which controls for the effect of cigarette-oriented policies independent of NVP use. We then compare these No-NVP projections to actual smoking rates derived from national surveys to estimate the net impact of NVPs on smoking prevalence and smoking-attributable deaths (SADs).

\section{Methods}

We first validate the model over the time period 1993-2012, before NVP use became more widespread. That model is then used to extrapolate trends in smoking prevalence in the absence of NVPs in the post-NVP period of 2012-2018, which is then compared to actual smoking prevalence.

\subsection{SimSmoke and the No-NVP Counterfactual}

The SimSmoke consists of separate components for the population by smoking status, smoking-attributable deaths, and tobacco control policies for years 1993 and onward [35,36]. The model is described briefly below and in more depth in a Technical Report available from the authors.

Actual and projected population estimates by age and gender were obtained from the US Census Bureau for years 1993-2052 [37,38]. We incorporated net international migration [39] and death rates distinguished by smoking status [2,40] to the population as it evolved from 1993. The model population projections through 2052 were validated against population estimates (1993-2015) and projections (2016-2052) by the US Census Bureau.

Data from the Tobacco Use Supplement-Current Population Survey (TUS-CPS) [41] were used to initialize current, former and never smoking prevalence in 1993. Current smokers were defined as individuals who have smoked more than 100 cigarettes in their lifetime and currently smoke either daily or some days. Former smokers were defined as those who were smokers but report that they are not smoking and were differentiated by the number of years since quit smoking. Never smokers have not smoked 100 cigarettes in their lifetime.

Transitions are measured net of death rates distinguished by smoking status. The death rates for never and current smokers by age, gender and year from 1993 to 2052 were based on estimates from the Cancer Intervention and Surveillance Modeling Network (CISNET) Lung consortium [2,40,42]. To estimate death rates for former smokers by years quit, the relative risk (RR) of former smokers by years quit was derived by first taking the ratio of current to never smoking death rates, i.e., smoker RR by age, gender and year and then applying a log-linear reduction to smoker RRs based on past studies as follows: [43-47] former smoker $R R=\exp [X * \log ($ smoker $R R)]$, where $X=100 \%$ for quit $<1$ year ago, $92.0 \%$ for quit $1-2$ years, $79.0 \%$ for quit $3-5$ years, $58.0 \%$ for quit $6-10$ years, $32.5 \%$ for quit $11-$ 15 years, and $8.0 \%$ for quit $>15$ years. Former smoker death rates by years quit were then obtained by multiplying the current smoker death rate by the ratio of the relative risks of current to former smokers.

A discrete, first-order Markov process was employed to simulate smoking initiation (never smoker to current smoker), cessation (current smoker to former smoker) and relapse (former smoker to current smoker). Because our goal was to develop initiation rates that reflect our measure of current smokers and because cessation is difficult to accurately measure at early ages, we measured net initiation by subtracting the 1993 current smoking prevalence at two consecutive ages divided by the 1993 never smoking prevalence at the 
younger age to estimate the 1993 initiation rates net of cessation, e.g., initiation at age $16=(1993$ smoking prevalence at age $16-1993$ smoking prevalence at age 15)/1993 never smoking prevalence at age 15 . Net initiation was measured from age 10 until the ages when smoking prevalence peaked: 22 for males and 25 for females. Cessation starts from the last age of net initiation and was obtained from the TUS-CPS. Cessation was measured as those who quit in the last year but not in the last three months [48]. This measure implicitly assumes that those who quit in the last 3 months (and are not counted) are offset by former smokers who quit but relapsed in months 3-12. Age- and gender-specific relapse rates [49-51] by years quit were then applied.

SimSmoke incorporates the impact of policies on initiation and cessation. The effects of the policies are generally applied as percentage reductions in smoking rates in the year when a new policy is implemented and as percentage change to initiation and cessation rates in future years. The percent reductions are applied multiplicatively when multiple policies are simultaneously in effect. SimSmoke policies and policy effect sizes are shown in Table 1. Policy levels are tracked over time beginning with their initial level in 1993 . The effect of a newly implemented policy depends on the incremental effect from previous levels of the same policy.

To gauge the tax/price policy effect, price changes are translated into changes in smoking prevalence through an equation dependent on price elasticities which vary by age $[3,6,52]$. Cigarette prices and taxes through 2019 were obtained from Tax Burden of Tobacco reports [53], and were adjusted for inflation using the Bureau of Labor Statistics (BLS) consumer price index [54].

Smoke-free air laws incorporate restrictions on (1) worksites, (2) restaurants, (3) bars, and (4) other public places $[6,55]$. The impact of smoke-free air laws depends on the extent of the ban and level of enforcement (based on compliance data) and publicity (based on the extent of media campaigns). Data on smoke-free air laws are from the American Nonsmokers Rights Foundation website by state and locality and is weighted by population [56]. For example, strict bans in 2019 were implemented in $76.1 \%$ of US worksites, $77.8 \%$ of US restaurants, $66.4 \%$ of US pubs and bars, and $95 \%$ of US other public places. Enforcement is set at level 8 out of 10 in all years [7].

Mass campaigns are gauged by average per capita expenditures for media campaigns, school education programs, and community interventions [6,57]. Total tobacco prevention spending [58] is divided by the US population to obtain spending per capita. Based on average expenditures, the policy level was set at $90 \%$ minimal and $10 \%$ moderate level from 1993 to 1994, increasing to $100 \%$ moderate level in 2003 . The level was reduced back to $50 \%$ minimal and 50\% moderate level during the period 2011-2017 but returned to a $25 \%$ minimal and $75 \%$ moderate level in the period 2018-2019 [3,7].

Marketing restrictions correspond to the type of bans on advertising and marketing and depend on enforcement [6]. Federal laws prohibit cigarette advertising, except at retail point-of-sale and in newspapers and magazines. Restrictions on advertising were set to a minimal level from 1993 through 2009, then increased to $25 \%$ moderate and $75 \%$ minimal level in 2010 with added FDA restrictions. Enforcement was set at level 9 out of 10 for all years [3,7].

US health warnings were maintained at a low level from 1993 to 2019 since text-only warnings covered less than $10 \%$ of packages for all years.

Cessation treatment policies include pharmacotherapy (PT) availability, financial coverage of treatments, quitlines and health care provider brief interventions $[59,60]$. Nicotine replacement therapy (NRT, gum) has been available since 1988, with the addition of the patch in 1993. Bupropion has been provided with a prescription since 1998. Treatment coverage was initiated in stages beginning with 30\% coverage in 1997 increasing to $40 \%$ in $2002,50 \%$ in 2007 , and $75 \%$ in 2014 . A national quitline was implemented from $50 \%$ in 2003 increasing in stages to $90 \%$ in 2007. Brief interventions are set at $50 \%$ coverage for all years [59]. 
Table 1. Tobacco control policies, specifications and effect sizes applied in US SimSmoke.

\begin{tabular}{|c|c|c|c|}
\hline Policy & Description & Policy Effect Size & Policy Level, 1993-2019 \\
\hline \multicolumn{4}{|c|}{ Cigarette Excise Taxes } \\
\hline $\begin{array}{l}\text { Cigarette } \\
\text { price/tax }\end{array}$ & $\begin{array}{l}\text { The effect of taxes is directly incorporated through the average price after } \\
\text { tax. The price elasticity is used to convert the price changes (\%) into effect } \\
\text { sizes }\end{array}$ & $\begin{array}{c}\text { Elasticities } \\
-0.6 \text { for ages } 14-17 \\
-0.4 \text { for ages } 18-24 \\
-0.2 \text { for ages } 25-34 \\
-0.1 \text { for ages } 35-64 \\
-0.2 \text { for ages } 65+\end{array}$ & $\begin{array}{l}\text { The inflation-adjusted cigarette price increased from } \\
\$ 1.75 \text { per pack in } 1993 \text { to } \$ 3.6 \text { in } 2002 \text { to } \$ 5.60 \text { in } 2012 \\
\text { and } \$ 6.60 \text { in } 2019 .\end{array}$ \\
\hline $\begin{array}{l}\text { Worksite } \\
\text { smoking ban }\end{array}$ & $\begin{array}{l}\text { Ban in all indoor worksites, with strong enforcement of laws (reduced by } \\
1 / 3 \text { if allowed in ventilated areas and by } 2 / 3 \text { if allowed in common areas) }\end{array}$ & $\begin{array}{l}-6 \% \text { prevalence and initiation, }+6 \% \\
\text { cessation }\end{array}$ & \multirow{4}{*}{$\begin{array}{l}\text { Worksite ban was at } 37 \% \text { low } 7 \% \text { mid and } 1.5 \% \text { high } \\
\text { with little increase through } 2002 \text { and gradually } \\
\text { increased to } 76.1 \% \text { high and } 10.4 \% \text { mid and } 13.5 \% \text { low } \\
\text { in } 2019 \text {. Restaurant ban were less than } 1 \% \text { before } 2002 \\
\text { and gradually increased to } 77 \% \text { by } 2014 \text { with little } \\
\text { further change. Bars ban was } 0 \text { until } 2001 \text { and gradually } \\
\text { increased to } 65 \% \text { by } 2014 \text {. Ban in other places was } 50 \% \\
\text { before } 1999 \text { increasing to } 94.8 \% \text { by } 2012 \text {. }\end{array}$} \\
\hline $\begin{array}{l}\text { Restaurant } \\
\text { smoking ban }\end{array}$ & $\begin{array}{c}\text { Ban in all indoor restaurants (scaled for lower coverage), with strong } \\
\text { enforcement of laws }\end{array}$ & $\begin{array}{l}-2 \% \text { prevalence and initiation, }+2 \% \\
\text { cessation }\end{array}$ & \\
\hline $\begin{array}{l}\text { Pubs and bars } \\
\text { smoking ban }\end{array}$ & $\begin{array}{c}\text { Ban in all indoor in pubs and bars (scaled for lower coverage), with strong } \\
\text { enforcement of laws }\end{array}$ & $\begin{array}{l}-1 \% \text { prevalence and initiation, }+1 \% \\
\text { cessation }\end{array}$ & \\
\hline $\begin{array}{l}\text { Other place } \\
\text { bans }\end{array}$ & $\begin{array}{l}\text { Ban in } 3 \text { out of } 4 \text { government buildings (scaled for lower coverage), retail } \\
\text { stores, public transportation, and elevators, with strong enforcement of laws }\end{array}$ & $\begin{array}{l}-1 \% \text { prevalence and initiation, }+1 \% \\
\text { cessation }\end{array}$ & \\
\hline $\begin{array}{l}\text { Enforcement } \\
\text { and Publicity }\end{array}$ & $\begin{array}{l}\text { Government agency enforces the laws and publicity via tobacco control } \\
\text { campaigns }\end{array}$ & $\begin{array}{l}\text { Enforcement is ranked on a } 1-10 \\
\text { scale converted to percentage terms } \\
\text { and publicity is based on indicator }= \\
1 \text { if media campaigns are at a } \\
\text { medium level. Effects reduced } 50 \% \\
\text { absent publicity and enforcement; } \\
\text { Effect sizes are deflated by: } 0.5^{*}(1+ \\
0.5^{*} \text { Publicity Indicator }+0.5^{*} \\
\text { Enforcement Level). }\end{array}$ & $\begin{array}{c}\text { The enforcement level is } 8 \text { out of } 10 \text { in all years and the } \\
\text { publicity level is based on the level of the media } \\
\text { campaigns. }\end{array}$ \\
\hline
\end{tabular}


Table 1. Cont

\begin{tabular}{|c|c|c|c|c|c|}
\hline Policy & & Description & Policy Effect Size & \multicolumn{2}{|r|}{ Policy Level, 1993-2019 } \\
\hline \multicolumn{6}{|c|}{ Media Campaigns } \\
\hline $\begin{array}{l}\text { High level } \\
\text { media campaign }\end{array}$ & \multicolumn{2}{|c|}{$\begin{array}{c}\text { Campaign publicized heavily with state and local programs with } \\
\text { strong funding ( } \$ 0.50 \text { USD) }\end{array}$} & $\begin{array}{l}-6.5 \% \text { prevalence and } \\
\text { initiation, }+6.5 \% \text { cessation }\end{array}$ & \multirow{3}{*}{\multicolumn{2}{|c|}{$\begin{array}{l}\text { Campaigns at } 90 \% \text { minimal and } 10 \% \text { moderate level, increasing to } \\
100 \% \text { moderate level in } 2003 \text {, and reduced back to } 50 \% \text { minimal and } \\
50 \% \text { moderate level from } 2011 \text { to } 2017 \text {, then returning to a } 25 \% \text { minimal } \\
\text { and } 75 \% \text { moderate level in the period } 2018-2019 \text {. }\end{array}$}} \\
\hline $\begin{array}{l}\text { Medium level } \\
\text { media campaign }\end{array}$ & \multicolumn{2}{|c|}{ Campaign publicized with funding of at least $\$ 0.10$ USD per capita } & $\begin{array}{l}-3.25 \% \text { prevalence and } \\
\text { initiation, }+3.25 \% \text { cessation }\end{array}$ & & \\
\hline $\begin{array}{l}\text { Low level media } \\
\text { campaign }\end{array}$ & Campaign pul & $\begin{array}{l}\text { licized only sporadically with minimal funding } \\
\quad(<\$ 0.10 \text { USD per capita) }\end{array}$ & $\begin{array}{l}-1.63 \% \text { prevalence and } \\
\text { initiation, }+1.63 \% \text { cessation }\end{array}$ & & \\
\hline \multicolumn{6}{|c|}{ Marketing Restrictions } \\
\hline \multicolumn{2}{|c|}{ Comprehensive marketing ban } & $\begin{array}{l}\text { Ban on all forms of direct advertising including point of sale and } \\
\text { indirect marketing }\end{array}$ & \multicolumn{2}{|c|}{$\begin{array}{l}-5 \% \text { prevalence, } \\
-8 \% \text { initiation, } \\
+4 \% \text { cessation }\end{array}$} & \multirow{3}{*}{$\begin{array}{c}\text { Restrictions on marketing were at minimal level from } \\
1993 \text { through 2009, then increased to } 25 \% \text { moderate } \\
\text { and } 75 \% \text { minimal level in } 2010 \text { with added FDA } \\
\text { restrictions. }\end{array}$} \\
\hline \multicolumn{2}{|c|}{ Moderate marketing ban } & $\begin{array}{c}\text { Ban on broadcast media, newspapers and billboards marketing } \\
\text { and at least some indirect marketing (sponsorship, branding, } \\
\text { giveaways) }\end{array}$ & \multicolumn{2}{|c|}{$\begin{array}{l}-3 \% \text { prevalence, } \\
-4 \% \text { initiation, } \\
+2 \% \text { cessation }\end{array}$} & \\
\hline \multicolumn{2}{|c|}{ Minimal marketing ban } & Ban on broadcast media advertising & \multicolumn{2}{|c|}{$\begin{array}{l}-1 \% \text { prevalence and }-1 \% \\
\text { initiation only }\end{array}$} & \\
\hline \multicolumn{2}{|c|}{ Enforcement } & Government agency enforces the laws & \multicolumn{2}{|c|}{$\begin{array}{l}\text { Effects reduced } 50 \% \text { absent } \\
\text { enforcement }\end{array}$} & Level 9 out of 10 for all years. \\
\hline \multicolumn{6}{|c|}{ Cessation Treatment Policies } \\
\hline \multicolumn{2}{|c|}{ Availability of pharmaco-therapies } & $\begin{array}{l}\text { Legality of nicotine replacement } \\
\text { therapy (NRT) and/or } \\
\text { Bupropion and Varenicline }\end{array}$ & $\begin{array}{l}-1 \% \text { prevalence } \\
+4 \% \text { cessation }\end{array}$ & & $\begin{array}{l}\text { Availability of NRT since 1993, and } \\
\text { Bupropion with a prescription since } \\
\text { 1998. Treatment coverage increased in } \\
\text { stages from } 30 \% \text { coverage in } 1997 \text { to } \\
40 \% \text { in } 2002 \text {, to } 50 \% \text { in } 2007 \text {, and to } \\
75 \% \text { in } 2014 \text {. A national quitline was } \\
\text { implemented at } 50 \% \text { in } 2003 \text { increasing } \\
\text { in stages to } 90 \% \text { in } 2007 \text {. Brief } \\
\text { interventions are set at } 50 \% \text { coverage } \\
\text { for all years. }\end{array}$ \\
\hline
\end{tabular}


Table 1. Cont.

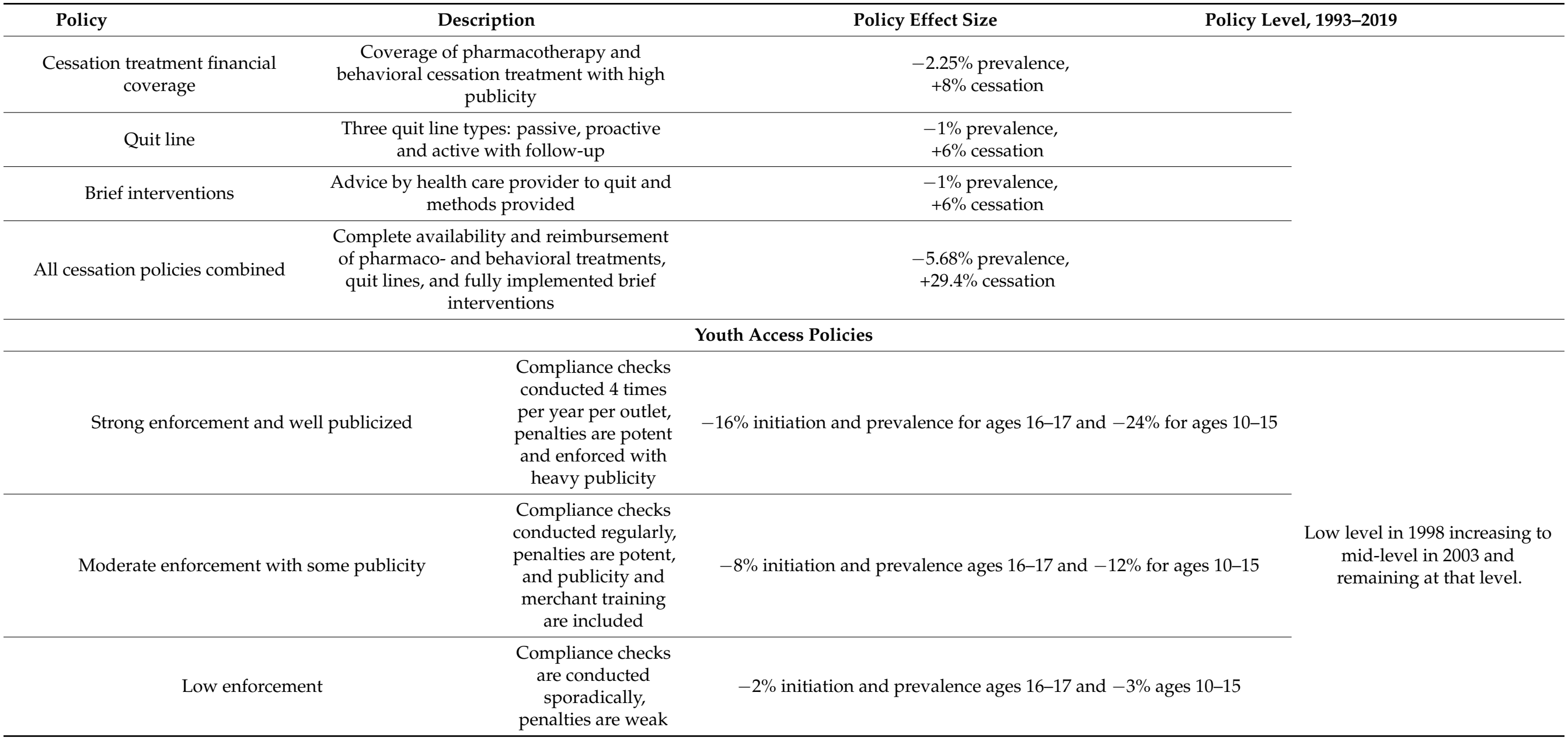

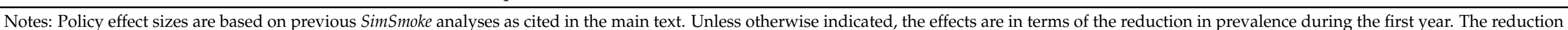

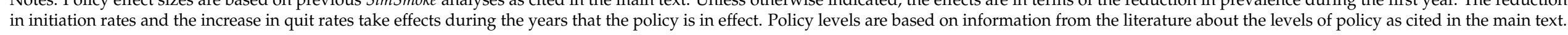


Youth access policy considers the effect of retail compliance with minimum purchase age restrictions and self-service and vending machine bans [61]. Youth access enforcement increased to low level in 1998 and to mid-level in 2003, based on non-compliance rates of about $10 \%[3,7]$.

Vending machine ban coverage increased from $50 \%$ in 1993 to $75 \%$ by 2000 and $100 \%$ by 2010 . Self-service bans begin at 50\% in 1995 increasing to 100\% in 2010 [3,7].

\subsection{Calibration and Validation}

We first validated the model prior to 2012, before NVP use became more widespread in the US. NVP use was minimal in the US until $2013[23,62,63]$, when third-generation vaping devices became available that delivered nicotine more efficiently than previous-generation devices [14-16]. Adult NVP use increased substantially and reached 3-5\% in 2013, with as much as $20 \%$ use among current and recent former smokers $[62,64,65]$. Therefore, we designate the years 1993-2012 as the pre-NVP period, which is used to project the No-NVP counterfactual after 2012.

SimSmoke smoking prevalence was first calibrated against prevalence estimates by age and gender from the TUS-CPS and the National Health Interview Survey (NHIS) over the period 1993-1998, a period of little policy change. For 1993 and the ensuing years, the initiation rates were increased by $30 \%$ for males and $15 \%$ for females primarily to reflect the increasing smoking prevalence among young adults over that time period. The increase in smoking among youth has been associated with the "Joe Camel" campaign in the early nineties [66-68].

We then validate over the pre-NVP period. SimSmoke smoking prevalence projections by gender and age group are compared against national surveys. With TUS-CPS available every three to four years, we first validated through 2010/11, the year closest to and before 2012. We also use estimates from the annual NHIS to validate the model through 2012. Because initial prevalence levels differ across surveys and from SimSmoke, we compared relative changes in smoking prevalence from 1998 to 2012 as [(SmokPrev 2012SmokPrev ${ }_{1998}$ )/SmokPrev ${ }_{1998}$ ]. We also examined whether SimSmoke projections are within the confidence intervals (CI) of the survey estimates. The validated 1993-2012 model is then used to extrapolate post-2012 trends in smoking prevalence under the No-NVP counterfactual.

\subsection{The Impact of NVPs}

The impact of NVPs is inferred by comparing smoking projections by age and gender in the period 2012-2018 under the No-NVP counterfactual scenario to actual smoking prevalence during the post-NVP 2012-2018 period from surveys. To estimate the changes in smoking prevalence reflective of NVP use, we subtract the SimSmoke projected relative change in smoking prevalence between 2012 and 2018 in the No-NVP counterfactual scenario from the corresponding estimated relative change in smoking prevalence from TUS-CPS and NHIS. Because the TUS-CPS is not available in 2012, the prevalence in that year is estimated as a weighted average of TUS-CPS estimates in 2010/2011 (60\% weight) and 2014/15 (40\% weight). We tested for differences in the counterfactual and actual estimates by considering whether the projected 2012-2018 SimSmoke relative changes are outside of the corresponding CIs from the TUS-CPS and NHIS relative changes.

As a gauge of uncertainty for the implied NVP impacts, we use the $95 \%$ CIs of the 2018 survey estimates as upper and lower bound estimates for smoking prevalence in 2018. We then estimated net NVP impacts by comparing relative changes in SimSmoke projections to the relative reductions based on the upper and lower bounds (e.g., upper bound of the relative reduction $=$ (upper bound of 2018 prevalence- 2012 prevalence) $/ 2012$ prevalence) We also conducted sensitivity analyses based on the uncertainty around the policy effects in our 2012-2018 projections, by applying upper and lower bounds for each policy's effects $(+/-25 \%$ of the effects for taxes and $+/-50 \%$ of the effects for other policies) based on a literature review [6]. 
To estimate the impact of NVPs on smoking-attributable deaths (SADs), we first obtained the NVP-adjusted smoking prevalence by incorporating the inferred NVP-related reduction in smoking prevalence for each survey back into the model. Separate yearly adjustments by gender and age are used to obtain the NVP-adjusted SimSmoke prevalence, i.e., the No-NVP projections each year were reduced in relative terms by the average annual reduction rate [(1- survey smoking relative reduction in the period 2012-2018) ${ }^{1 / 6}$ (1- SimSmoke smoking relative reduction in the period 2012-2018) ${ }^{1 / 6}$ ], which is also called the NVP adjustor. The NVP-adjusted annual reduction is transferred to never smokers if under the age of 25 or former smokers if above 25 .

Once the NVP-adjusted smoking rates were obtained, we separately estimate SADs under the No-NVP and NVP-adjusted SimSmoke by multiplying the number of current smokers at each age by their excess mortality risks (current smoker death rate-never smoker death rate). The same procedure is applied to former smokers and summed over current and former smokers to obtain total SADs. The potential public health impact of 2012-2018 NVP use is measured as the difference in SADs between the NVP-adjusted and the No-NVP SimSmoke between 2012 and 2052.

\section{Results}

\subsection{Validation of Smoking Prevalence Estimates over the Pre-NVP Period}

As shown in Figure 1a,b, the projections for males and females in the No-NVP counterfactual scenario are compared to actual trends, especially for the post-NVP period (after 2012). The gender- and age-specific SimSmoke, TUS-CPS and NHIS smoking prevalence estimates from 1993 to 2012 are presented in Table 2. Validating against the survey estimates over the period 1998-2010, SimSmoke yielded a relative reduction in adult (age 18+) male prevalence of $28.8 \%$ compared to $29.6 \%$ from TUS-CPS and $18.6 \%$ from NHIS. The SimSmoke projected 2010 male smoking prevalence was $17.9 \%$ compared to $17.2 \%$ from TUS-CPS and $21.5 \%$ from NHIS. For adult females, SimSmoke yielded a relative reduction of 30.8\% compared to $31.3 \%$ from TUS-CPS and $21.4 \%$ from NHIS. The SimSmoke 2010 female smoking prevalence was $14.0 \%$ compared to 13.7\% from TUS-CPS and 17.3\% from NHIS. Between 1998 and 2012, SimSmoke adult male prevalence declined by $31.2 \%$ (2012 prevalence: $17.3 \%$ ) compared to $22.3 \%$ from NHIS (2012 prevalence: $20.5 \%$ ). SimSmoke female smoking prevalence declined by 33.3\% (2012 prevalence:13.5\%) compared to $28.2 \%$ from NHIS (2012 prevalence: $15.8 \%$ ).

For ages 18-24, SimSmoke male smoking prevalence declined by $31.6 \%$ (2010 prevalence: $19.8 \%$ ) from 1998 to 2010 compared to $35.4 \%$ from TUS-CPS (2010 prevalence: $19.4 \%$ ) and $27.2 \%$ from NHIS (2010 prevalence: $22.8 \%$ ). For female counterparts, the relative reduction was $34.4 \%$ from SimSmoke compared to $40.3 \%$ from TUS-CPS and $29.0 \%$ from NHIS. For males of ages 25-44, the relative reductions was 28.1\% from SimSmoke compared to $30.9 \%$ from TUS-CPS and $17.3 \%$ from NHIS. For females of ages $25-44$, the relative reduction from SimSmoke was 31.0\% compared to 34.2\% from TUS-CPS and $22.7 \%$ from NHIS. For males of ages 45-64, the SimSmoke relative reduction was 26.3\% compared to relative reductions of $25.6 \%$ from a TUS-CPS and $16.2 \%$ from NHIS. For females of ages 45-64, the relative reduction from SimSmoke was $28.8 \%$ compared to $22.2 \%$ from TUS-CPS and $15.1 \%$ from NHIS. For males of ages 65 and above, the SimSmoke relative reduction was $26.8 \%$ compared to $20.1 \%$ from TUS-CPS and $6.7 \%$ from NHIS. For females of ages 65 and above, the SimSmoke relative reduction was $27.0 \%$ from compared to $28.6 \%$ from TUS-CPS and $17.0 \%$ from NHIS.

The levels of smoking prevalence in 2010 and the relative reductions between 1998 and 2010 from SimSmoke were generally between those of the NHIS and TUS-CPS but closer to those of the TUS-CPS for the different age groups. All SimSmoke estimates of 2010 smoking prevalence were within the $95 \%$ CIs for TUS-CPS estimates, except for females of ages $45-64$ (within $0.1 \%$ ) and males $18+$ (within $0.3 \%$ ). There was less alignment with NHIS. Relative reductions from 1993 to 2012 from SimSmoke were greater than those from NHIS, except for ages 18-24 (and 65+ for women), but the NHIS relative reductions were sensitive to years considered in the estimation. 


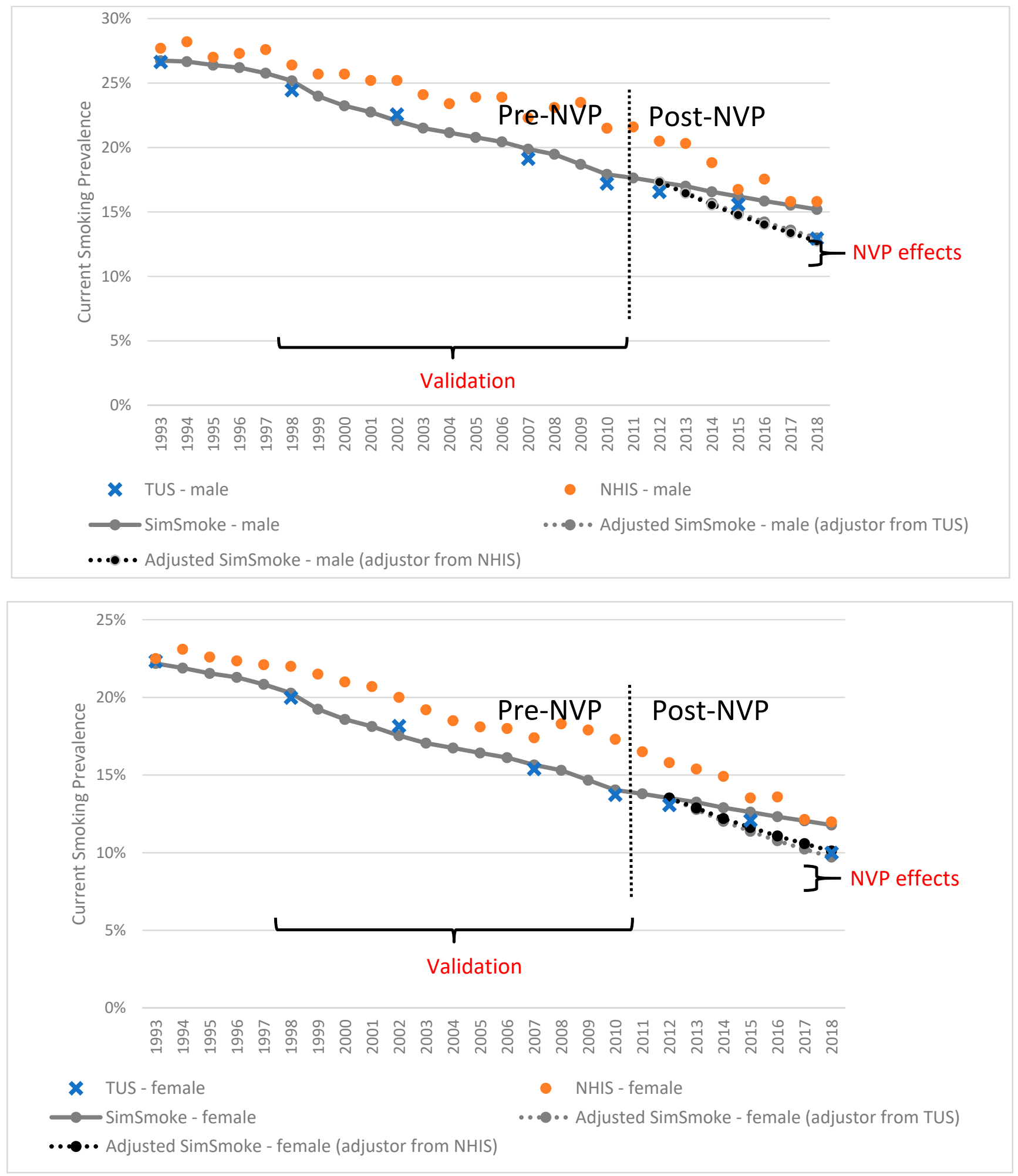

Figure 1. Smoking prevalence in surveys and the SimSmoke model with/without the NVP adjustors by sex, ages 18 and above, 1993-2018. 
Table 2. Calibration and validation of US SimSmoke current smoking prevalence predictions against national surveys, by age and gender, 1993-2012.

\begin{tabular}{|c|c|c|c|c|c|c|c|c|}
\hline Ages & Source & 1993 & 1998 & 2010 & 2012 & $\begin{array}{c}\text { Percent } \\
\text { Change } \\
\text { 1993-1998 }\end{array}$ & $\begin{array}{c}\text { Percent } \\
\text { Change } \\
\text { 1998-2010 }\end{array}$ & $\begin{array}{c}\text { Percent } \\
\text { Change } \\
\text { 1998-2012 }\end{array}$ \\
\hline \multicolumn{9}{|c|}{ MALE } \\
\hline \multirow{4}{*}{$18+$} & SimSmoke & $26.7 \%$ & $25.2 \%$ & $17.9 \%$ & $17.3 \%$ & $-5.8 \%$ & $-28.8 \%$ & $-31.2 \%$ \\
\hline & TUS-CPS & $26.6 \%$ & $24.4 \%$ & $17.2 \%$ & & $-8.2 \%$ & $-29.6 \%$ & \\
\hline & $95 \%$ CI & $(26.3 \%, 27.0 \%)$ & $(23.9 \%, 25.0 \%)$ & $(16.8 \%, 17.6 \%)$ & & & & \\
\hline & NHIS & $\begin{array}{c}27.7 \% \\
\%\end{array}$ & $\begin{array}{l}26.4 \% \\
5 \%\end{array}$ & $\begin{array}{c}21.5 \% \\
7 \%\end{array}$ & $20.5 \%$ & $-4.7 \%$ & $-18.6 \%$ & $-22.3 \%$ \\
\hline \multirow{6}{*}{$18-24$} & & & & & & & & \\
\hline & SimSmoke & $27.3 \%$ & $29.0 \%$ & $19.8 \%$ & $19.9 \%$ & $6.4 \%$ & $-31.6 \%$ & $-31.5 \%$ \\
\hline & TUS-CPS & $27.7 \%$ & $30.0 \%$ & $19.4 \%$ & & $8.0 \%$ & $-35.4 \%$ & \\
\hline & $95 \%$ CI & $(26.7 \%, 28.7 \%)$ & $(27.9 \%, 32.0 \%)$ & $(18.0 \%, 20.7 \%)$ & & & & \\
\hline & NHIS & $28.8 \%$ & $31.3 \%$ & $22.8 \%$ & $20.1 \%$ & $8.7 \%$ & $-27.2 \%$ & $-35.8 \%$ \\
\hline & $95 \% \mathrm{CI}$ & $(25.5 \%, 32.1 \%)$ & $(28.4 \%, 34.2 \%)$ & $(19.9 \%, 25.7 \%)$ & $(17.1 \%, 23.1 \%)$ & & & \\
\hline \multirow{5}{*}{$25-44$} & SimSmoke & $30.7 \%$ & $28.1 \%$ & $20.2 \%$ & $19.6 \%$ & $-8.3 \%$ & $-28.1 \%$ & $-30.2 \%$ \\
\hline & TUS-CPS & $30.8 \%$ & $28.4 \%$ & $19.6 \%$ & & $-7.7 \%$ & $-30.9 \%$ & \\
\hline & $95 \%$ CI & $(30.3 \%, 31.3 \%)$ & $(27.5 \%, 29.4 \%)$ & $(19.0 \%, 20.3 \%)$ & & & & \\
\hline & NHIS & $31.1 \%$ & $29.4 \%$ & $24.3 \%$ & $25.4 \%$ & $-5.5 \%$ & $-17.3 \%$ & $-13.6 \%$ \\
\hline & $95 \% \mathrm{CI}$ & $(29.5 \%, 32.7 \%)$ & $(28.1 \%, 30.7 \%)$ & $(22.8 \%, 25.8 \%)$ & $(23.8 \%, 27.1 \%)$ & & & \\
\hline \multirow{5}{*}{$45-64$} & SimSmoke & $27.0 \%$ & $26.0 \%$ & $19.1 \%$ & $18.2 \%$ & $-3.9 \%$ & $-26.3 \%$ & $-29.9 \%$ \\
\hline & TUS-CPS & $27.1 \%$ & $25.1 \%$ & $18.7 \%$ & & $-7.3 \%$ & $-25.6 \%$ & \\
\hline & $95 \%$ CI & $(26.5 \%, 27.7 \%)$ & $(24.1 \%, 26.2 \%)$ & $(18.1 \%, 19.3 \%)$ & & & & \\
\hline & NHIS & $29.2 \%$ & $27.7 \%$ & $23.2 \%$ & $20.2 \%$ & $-5.1 \%$ & $-16.2 \%$ & $-27.1 \%$ \\
\hline & $95 \%$ CI & $(27.2 \%, 31.2 \%)$ & $(26.1 \%, 29.3 \%)$ & $(21.6 \%, 24.8 \%)$ & $(18.8 \%, 21.6 \%)$ & & & \\
\hline \multirow{5}{*}{$65+$} & SimSmoke & $13.6 \%$ & $11.6 \%$ & $8.5 \%$ & $8.4 \%$ & $-14.7 \%$ & $-26.8 \%$ & $-27.6 \%$ \\
\hline & TUS-CPS & $13.4 \%$ & $10.7 \%$ & $8.6 \%$ & & $-20.2 \%$ & $-20.1 \%$ & \\
\hline & $95 \%$ CI & $(12.8 \%, 14.0 \%)$ & $(9.7 \%, 11.7 \%)$ & $(7.9 \%, 9.2 \%)$ & & & & \\
\hline & NHIS & $13.5 \%$ & $10.4 \%$ & $9.7 \%$ & $10.6 \%$ & $-23.0 \%$ & $-6.7 \%$ & $1.9 \%$ \\
\hline & $95 \%$ CI & $(11.3 \%, 15.7 \%)$ & $(9.1 \%, 11.7 \%)$ & $(8.3 \%, 11.1 \%)$ & $(9.3 \%, 12.0 \%)$ & & & \\
\hline \multicolumn{9}{|c|}{ FEMALE } \\
\hline \multirow{5}{*}{$18+$} & SimSmoke & $22.2 \%$ & $20.3 \%$ & $14.0 \%$ & $13.5 \%$ & $-8.6 \%$ & $-30.8 \%$ & $-33.3 \%$ \\
\hline & TUS-CPS & $22.3 \%$ & $20.0 \%$ & $13.7 \%$ & & $-10.5 \%$ & $-31.3 \%$ & \\
\hline & $95 \%$ CI & $(22.1 \%, 22.6 \%)$ & $(19.5 \%, 20.4 \%)$ & $(13.4 \%, 14.0 \%)$ & & & & \\
\hline & NHIS & $22.5 \%$ & $22.0 \%$ & $17.3 \%$ & $15.8 \%$ & $-2.2 \%$ & $-21.4 \%$ & $-28.2 \%$ \\
\hline & $95 \% \mathrm{CI}$ & $(21.6 \%, 23.4 \%)$ & $(21.2 \%, 22.8 \%)$ & $(16.5 \%, 18.1 \%)$ & $(15.1 \%, 16.5 \%)$ & & & \\
\hline \multirow{5}{*}{$18-24$} & SimSmoke & $23.7 \%$ & $23.9 \%$ & $15.7 \%$ & $15.7 \%$ & $1.1 \%$ & $-34.4 \%$ & $-34.4 \%$ \\
\hline & TUS-CPS & $23.9 \%$ & $24.7 \%$ & $14.7 \%$ & & $3.4 \%$ & $-40.3 \%$ & \\
\hline & $95 \%$ CI & $(23.0 \%, 24.7 \%)$ & $(23.0 \%, 26.5 \%)$ & $(13.7 \%, 15.8 \%)$ & & & & \\
\hline & NHIS & $22.9 \%$ & $24.5 \%$ & $17.4 \%$ & $14.5 \%$ & $7.0 \%$ & $-29.0 \%$ & $-40.8 \%$ \\
\hline & $95 \%$ CI & $(20.2 \%, 25.6 \%)$ & $(21.9 \%, 27.1 \%)$ & $(15.0 \%, 19.8 \%)$ & $(12.3 \%, 16.7 \%)$ & & & \\
\hline \multirow{5}{*}{$25-44$} & SimSmoke & $26.3 \%$ & $23.4 \%$ & $16.2 \%$ & $15.7 \%$ & $-10.9 \%$ & $-31.0 \%$ & $-33.1 \%$ \\
\hline & TUS-CPS & $26.4 \%$ & $23.8 \%$ & $15.7 \%$ & & $-9.9 \%$ & $-34.2 \%$ & \\
\hline & $95 \%$ CI & $(26.0 \%, 26.8 \%)$ & $(23.0 \%, 24.6 \%)$ & $(15.1 \%, 16.2 \%)$ & & & & \\
\hline & NHIS & $27.3 \%$ & $25.6 \%$ & $19.8 \%$ & $17.8 \%$ & $-6.2 \%$ & $-22.7 \%$ & $-30.5 \%$ \\
\hline & $95 \%$ CI & $(26 \%, 28.6 \%)$ & $(24.4 \%, 26.8 \%)$ & $(18.4 \%, 21.2 \%)$ & $(16.6 \%, 19.0 \%)$ & & & \\
\hline \multirow{5}{*}{$45-64$} & SimSmoke & $23.1 \%$ & $21.5 \%$ & $15.3 \%$ & $14.4 \%$ & $-6.7 \%$ & $-28.8 \%$ & $-33.1 \%$ \\
\hline & TUS-CPS & $23.2 \%$ & $20.5 \%$ & $15.9 \%$ & & $-11.9 \%$ & $-22.2 \%$ & \\
\hline & $95 \% \mathrm{CI}$ & $(22.7 \%, 23.7 \%)$ & $(19.6 \%, 21.3 \%)$ & $(15.4 \%, 16.4 \%)$ & & & & \\
\hline & NHIS & $23.0 \%$ & $22.5 \%$ & $19.1 \%$ & $18.9 \%$ & $-2.2 \%$ & $-15.1 \%$ & $-16.0 \%$ \\
\hline & $95 \%$ CI & $(21.3 \%, 24.7 \%)$ & $(21.2 \%, 23.8 \%)$ & $(17.9 \%, 20.3 \%)$ & $(17.6 \%, 20.2 \%)$ & & & \\
\hline \multirow{5}{*}{$65+$} & SimSmoke & $11.3 \%$ & $9.8 \%$ & $7.1 \%$ & $7.1 \%$ & $-13.5 \%$ & $-27.0 \%$ & $-26.9 \%$ \\
\hline & TUS-CPS & $11.4 \%$ & $9.6 \%$ & $6.8 \%$ & & $-16.3 \%$ & $-28.6 \%$ & \\
\hline & $95 \%$ CI & $(11.0 \%, 11.9 \%)$ & $(8.8 \%, 10.3 \%)$ & $(6.4 \%, 7.3 \%)$ & & & & \\
\hline & NHIS & $10.5 \%$ & $11.2 \%$ & $9.3 \%$ & $7.5 \%$ & $6.7 \%$ & $-17.0 \%$ & $-33.0 \%$ \\
\hline & $95 \% \mathrm{CI}$ & $(9.2 \%, 11.8 \%)$ & $(10 \%, 12.4 \%)$ & $(8.1 \%, 10.5 \%)$ & $(6.6 \%, 8.5 \%)$ & & & \\
\hline
\end{tabular}

Notes: 1. TUS-CPS = Tobacco Use Supplement of Current Population Survey that measures those who have smoked 100 cigarettes or more in their lifetime and currently smoke daily or someday; 2 . NHIS = National Health Interview Survey that measures those who have smoked 100 cigarettes or more in their lifetime and now smoke every day or some days; 3 . 95\% CI refers to the $95 \%$ confidence interval for the prevalence. 


\subsection{Impact of NVPs on Smoking Prevalence Relative to a No-NVP Scenario, 2012-2018}

For the period 2012-2018, Table 3 shows the yearly levels and projected relative reductions in smoking prevalence from the No-NVP SimSmoke (counterfactual), TUS-CPS and NHIS. Table 3 also shows the net impact of NVPs as the difference between the No-NVP SimSmoke and survey relative reductions. The projected smoking prevalence for age 18 and above in the period 2012-2018 and the data from surveys are also illustrated in Figure 1a,b.

Table 3. Smoking prevalence predictions from No-NVP SimSmoke Counterfactual compared to national surveys, by age group and gender, 2012-2018.

\begin{tabular}{|c|c|c|c|c|c|c|c|}
\hline Age & Source & 2012 & 2018 & $\begin{array}{c}\text { Relative } \\
\text { Reduction } \\
2012-2018 \\
\end{array}$ & $\begin{array}{l}\text { Difference from } \\
\text { SimSmoke * }\end{array}$ & $\begin{array}{c}\text { Annual } \\
\text { Relative } \\
\text { Reduction }+\end{array}$ & $\begin{array}{c}\text { Annual } \\
\text { Difference from } \\
\text { SimSmoke }\end{array}$ \\
\hline \multicolumn{8}{|c|}{ MALE } \\
\hline \multirow{5}{*}{$18+$} & SimSmoke & $17.3 \%$ & $15.2 \%$ & $12.2 \%$ & & $2.1 \%$ & \\
\hline & TUS-CPS & $16.6 \%$ & $12.9 \%$ & $21.9 \%$ & $9.7 \%$ & $4.0 \%$ & $1.9 \%$ \\
\hline & $95 \%$ CI & & $(12.6 \%, 13.3 \%)$ & $(19.7 \%, 23.9 \%)$ & $(7.5 \%, 11.7 \%)$ & $(3.6 \%, 4.5 \%)$ & $(1.4 \%, 2.3 \%)$ \\
\hline & NHIS & $20.5 \%$ & $15.8 \%$ & $22.9 \%$ & $10.7 \%$ & $4.2 \%$ & $2.1 \%$ \\
\hline & $95 \% \mathrm{CI}$ & & $(15.0 \%, 16.6 \%)$ & $(19.0 \%, 26.8 \%)$ & $(6.8 \%, 14.6 \%)$ & $(3.5 \%, 5.1 \%)$ & $(1.3 \%, 2.9 \%)$ \\
\hline \multirow{5}{*}{$18-24$} & SimSmoke & $19.9 \%$ & $18.8 \%$ & $5.2 \%$ & & $0.9 \%$ & \\
\hline & TUS-CPS & $16.9 \%$ & $8.7 \%$ & $48.4 \%$ & $43.2 \%$ & $10.4 \%$ & $9.6 \%$ \\
\hline & $95 \% \mathrm{CI}$ & & $(7.7 \%, 9.9 \%)$ & $(41.6 \%, 54.5 \%)$ & $(36.4 \%, 49.3 \%)$ & $(8.6 \%, 12.3 \%)$ & $(7.7 \%, 11.4 \%)$ \\
\hline & NHIS & $20.1 \%$ & $8.5 \%$ & $57.8 \%$ & $52.6 \%$ & $13.4 \%$ & $12.5 \%$ \\
\hline & $95 \% \mathrm{CI}$ & & $(6.4 \%, 10.5 \%)$ & $(47.8 \%, 68.2 \%)$ & $(42.6 \%, 63.0 \%)$ & $(10.3 \%, 17.4 \%)$ & $(9.4 \%, 16.5 \%)$ \\
\hline \multirow{5}{*}{$25-44$} & SimSmoke & $19.6 \%$ & $18.2 \%$ & $7.5 \%$ & & $1.3 \%$ & \\
\hline & TUS-CPS & $19.1 \%$ & $14.5 \%$ & $24.3 \%$ & $16.8 \%$ & $4.5 \%$ & $3.3 \%$ \\
\hline & $95 \%$ CI & & $(13.9 \%, 15.1 \%)$ & $(21.0 \%, 27.3 \%)$ & $(13.5 \%, 19.8 \%)$ & $(3.9 \%, 5.2 \%)$ & $(2.6 \%, 3.9 \%)$ \\
\hline & NHIS & $25.4 \%$ & $19.1 \%$ & $24.8 \%$ & $17.3 \%$ & $4.6 \%$ & $3.3 \%$ \\
\hline & $95 \% \mathrm{CI}$ & & $(17.5 \%, 20.7 \%)$ & $(18.5 \%, 31.1 \%)$ & $(11.0 \%, 23.6 \%)$ & $(3.4 \%, 6.0 \%)$ & $(2.1 \%, 4.7 \%)$ \\
\hline \multirow{5}{*}{$45-64$} & SimSmoke & $18.2 \%$ & $15.0 \%$ & $17.4 \%$ & & $3.1 \%$ & \\
\hline & TUS-CPS & $18.2 \%$ & $15.5 \%$ & $14.9 \%$ & $-2.5 \%$ & $2.6 \%$ & $-0.5 \%$ \\
\hline & $95 \% \mathrm{CI}$ & & $(14.9 \%, 16.1 \%)$ & $(11.6 \%, 18.2 \%)$ & $(-5.8 \%, 0.8 \%)$ & $(2.0 \%, 3.3 \%)$ & $(-1.1 \%, 0.2 \%)$ \\
\hline & NHIS & $20.2 \%$ & $18.3 \%$ & $9.3 \%$ & $-8.1 \%$ & $1.6 \%$ & $-1.5 \%$ \\
\hline & $95 \% \mathrm{CI}$ & & $(16.9 \%, 19.7 \%)$ & $(2.5 \%, 16.3 \%)$ & $(-14.9 \%,-1.1 \%)$ & $(0.4 \%, 2.9 \%)$ & $(-2.7 \%,-0.2 \%)$ \\
\hline \multirow{5}{*}{$65+$} & SimSmoke & $8.4 \%$ & $7.4 \%$ & $11.4 \%$ & & $2.0 \%$ & \\
\hline & TUS-CPS & $8.6 \%$ & $8.4 \%$ & $3.2 \%$ & $-8.2 \%$ & $0.5 \%$ & $-1.4 \%$ \\
\hline & $95 \% \mathrm{CI}$ & & $(7.9 \%, 8.9 \%)$ & $(-3.0 \%, 8.5 \%)$ & $(-14.4 \%,-2.8 \%)$ & $(-0.5 \%, 1.5 \%)$ & $(-2.5 \%,-0.5 \%)$ \\
\hline & NHIS & $10.6 \%$ & $9.9 \%$ & $6.2 \%$ & $-5.2 \%$ & $1.1 \%$ & $-0.9 \%$ \\
\hline & $95 \% \mathrm{CI}$ & & $(8.7 \%, 11.1 \%)$ & $(-4.7 \%, 17.9 \%)$ & $(-16.1 \%, 6.6 \%)$ & $(-0.8 \%, 3.2 \%)$ & $(-2.8 \%, 1.2 \%)$ \\
\hline
\end{tabular}


Table 3. Cont

\begin{tabular}{|c|c|c|c|c|c|c|c|}
\hline Age & Source & 2012 & 2018 & $\begin{array}{c}\text { Relative } \\
\text { Reduction } \\
2012-2018\end{array}$ & $\begin{array}{l}\text { Difference from } \\
\text { SimSmoke }\end{array}$ & $\begin{array}{c}\text { Annual } \\
\text { Relative } \\
\text { Reduction }+\end{array}$ & $\begin{array}{c}\text { Annual } \\
\text { Difference from } \\
\text { SimSmoke }\end{array}$ \\
\hline \multicolumn{8}{|c|}{ FEMALE } \\
\hline \multirow{5}{*}{$18+$} & SimSmoke & $13.5 \%$ & $11.8 \%$ & $12.8 \%$ & & $2.3 \%$ & \\
\hline & TUS-CPS & $13.1 \%$ & $10.0 \%$ & $23.6 \%$ & $10.7 \%$ & $4.4 \%$ & $2.1 \%$ \\
\hline & $95 \% \mathrm{CI}$ & & $(9.7 \%, 10.2 \%)$ & $(22.0 \%, 25.8 \%)$ & $(9.1 \%, 13.0 \%)$ & $(4.1 \%, 4.9 \%)$ & $(1.8 \%, 2.6 \%)$ \\
\hline & NHIS & $15.8 \%$ & $12.0 \%$ & $24.2 \%$ & $11.3 \%$ & $4.5 \%$ & $2.2 \%$ \\
\hline & $95 \% \mathrm{CI}$ & & $(11.3 \%, 12.6 \%)$ & $(20.3 \%, 28.5 \%)$ & $(7.4 \%, 15.6 \%)$ & $(3.7 \%, 5.4 \%)$ & $(1.4 \%, 3.2 \%)$ \\
\hline \multirow{5}{*}{ 18-24 } & SimSmoke & $15.7 \%$ & $14.9 \%$ & $5.3 \%$ & & $0.9 \%$ & \\
\hline & TUS-CPS & $12.5 \%$ & $6.1 \%$ & $51.2 \%$ & $45.9 \%$ & $11.3 \%$ & $10.4 \%$ \\
\hline & $95 \% \mathrm{CI}$ & & $(5.3 \%, 7.0 \%)$ & $(44.1 \%, 57.7 \%)$ & $(38.9 \%, 52.4 \%)$ & $(9.3 \%, 13.4 \%)$ & $(8.3 \%, 12.5 \%)$ \\
\hline & NHIS & $14.5 \%$ & $7.3 \%$ & $49.7 \%$ & $44.4 \%$ & $10.8 \%$ & $9.9 \%$ \\
\hline & $95 \% \mathrm{CI}$ & & $(5.2 \%, 9.4 \%)$ & $(35.2 \%, 64.1 \%)$ & $(29.9 \%, 58.8 \%)$ & $(7.0 \%, 15.7 \%)$ & $(6.1 \%, 14.8 \%)$ \\
\hline \multirow{5}{*}{$25-44$} & SimSmoke & $15.7 \%$ & $14.2 \%$ & $9.2 \%$ & & $1.6 \%$ & \\
\hline & TUS-CPS & $14.9 \%$ & $10.6 \%$ & $28.9 \%$ & $19.8 \%$ & $5.5 \%$ & $3.9 \%$ \\
\hline & $95 \% \mathrm{CI}$ & & $(10.2 \%, 11.1 \%)$ & $(25.6 \%, 31.6 \%)$ & $(16.4 \%, 22.4 \%)$ & $(4.8 \%, 6.1 \%)$ & $(3.2 \%, 4.5 \%)$ \\
\hline & NHIS & $17.8 \%$ & $14.2 \%$ & $20.2 \%$ & $11.1 \%$ & $3.7 \%$ & $2.1 \%$ \\
\hline & $95 \% \mathrm{CI}$ & & $(12.9 \%, 15.5 \%)$ & $(12.9 \%, 27.5 \%)$ & $(3.8 \%, 18.4 \%)$ & $(2.3 \%, 5.2 \%)$ & $(0.7 \%, 3.6 \%)$ \\
\hline \multirow{5}{*}{$45-64$} & SimSmoke & $14.4 \%$ & $11.9 \%$ & $17.6 \%$ & & $3.2 \%$ & \\
\hline & TUS-CPS & $15.4 \%$ & $13.2 \%$ & $14.5 \%$ & $-3.1 \%$ & $2.6 \%$ & $-0.6 \%$ \\
\hline & $95 \% \mathrm{CI}$ & & $(12.7 \%, 13.7 \%)$ & $(11.1 \%, 17.6 \%)$ & $(-6.5 \%, 0.0 \%)$ & $(1.9 \%, 3.2 \%)$ & $(-1.2 \%, 0.0 \%)$ \\
\hline & NHIS & $18.9 \%$ & $14.3 \%$ & $24.5 \%$ & $6.9 \%$ & $4.6 \%$ & $1.4 \%$ \\
\hline & $95 \% \mathrm{CI}$ & & $(13.1 \%, 15.5 \%)$ & $(18.0 \%, 30.7 \%)$ & $(0.4 \%, 13.1 \%)$ & $(3.3 \%, 5.9 \%)$ & $(0.1 \%, 2.8 \%)$ \\
\hline \multirow{5}{*}{$65+$} & SimSmoke & $7.1 \%$ & $6.6 \%$ & $7.7 \%$ & & $1.3 \%$ & \\
\hline & TUS-CPS & $6.8 \%$ & $6.3 \%$ & $6.9 \%$ & $-0.8 \%$ & $1.2 \%$ & $-0.1 \%$ \\
\hline & $95 \% \mathrm{CI}$ & & $(6.0 \%, 6.7 \%)$ & $(1.5 \%, 11.8 \%)$ & $(-6.2 \%, 4.1 \%)$ & $(0.2 \%, 2.1 \%)$ & $(-1.1 \%, 0.7 \%)$ \\
\hline & NHIS & $7.5 \%$ & $7.3 \%$ & $2.5 \%$ & $-5.2 \%$ & $0.4 \%$ & $-0.9 \%$ \\
\hline & $95 \% \mathrm{CI}$ & & $(6.4 \%, 8.2 \%)$ & $(-9.3 \%, 14.7 \%)$ & $(-17.0 \%, 7.0 \%)$ & $(-1.5 \%, 2.6 \%)$ & $(-2.8 \%, 1.3 \%)$ \\
\hline
\end{tabular}

Notes: 1. TUS-CPS = Tobacco Use Supplement of Current Population Survey that measures those who have smoked 100 cigarettes or more in their lifetime and currently smoke daily or someday. 2. NHIS = National Health Interview Survey that measures those who have smoked 100 cigarettes or more in their lifetime and now smoke every day or some days. 3. Due to unavailable TUS-CPS data in 2012, the prevalence in that year is estimated from a weighted average of TUS-CPS estimates in 2010/2011 (60\% weight) and 2014/15 (40\% weight). $4.95 \%$ CI refers to the $95 \%$ confidence interval for the prevalence. * Difference of smoking relative reduction in the period $2012-2018$ between the model and surveys; + the No-NVP projections each year were reduced in relative terms by the average annual reduction rate [(1- survey smoking relative reduction in the period 2012-2018) ${ }^{1 / 6}\left(1 \text { - SimSmoke smoking relative reduction in the period 2012-2018) }{ }^{1 / 6}\right]^{+{ }^{++}}$difference of annual relative reduction between the model and surveys.

For adult males, No-NVP SimSmoke projects a relative reduction in smoking prevalence of $12.2 \%$. The TUS-CPS shows a relative reduction of $21.9 \%$ (95\% CI $=19.7-23.9 \%)$, implying a 9.7\% (95\% CI $=7.5-11.7 \%)$ net NVP-related reduction, while NHIS yields a relative reduction in prevalence of $22.9 \%(95 \% \mathrm{CI}=19.0-26.8 \%)$, implying a $10.7 \%(95 \% \mathrm{CI}=6.8-14.6 \%)$ net $\mathrm{NVP}-$ related reduction. For adult females, net relative reductions of $10.7 \%(95 \% \mathrm{CI}=9.1-13.0 \%)$ are implied using TUS-CPS and $11.3 \%(95 \% \mathrm{CI}=7.4-15.6 \%)$ using NHIS. For both genders, the No-NVP SimSmoke projected level is outside of the 95\% CI levels in 2018 for NHIS and TUS-CPS and the 2012-2018 relative reductions in smoking prevalence are outside of the $95 \%$ CI levels of the relative reductions for both TUS-CPS and NHIS. 
The largest relative reductions in smoking prevalence occur among younger age groups. For ages 18-24, the net NVP-related relative reductions of $43.2 \%$ (95\% CI $=36.4-$ $49.3 \%$ ) for males and $45.9 \%(95 \% \mathrm{CI}=38.9-52.4 \%)$ for females are implied by TUS-CPS, compared to $52.6 \%(95 \% \mathrm{CI}=42.6-63.0 \%)$ for males and $44.4 \%(95 \% \mathrm{CI}=29.9-58.8 \%)$ for females from NHIS. For ages 25-44, TUS-CPS implies $16.8 \%(95 \% \mathrm{CI}=13.5-19.8 \%)$ male and $19.8 \%(95 \% \mathrm{CI}=16.4-22.4 \%)$ female net reductions in smoking prevalence, while NHIS implies $17.3 \%(95 \% \mathrm{CI}=11.0-23.6 \%)$ and $11.1 \%(95 \% \mathrm{CI}=3.8-18.4 \%)$ reductions for males and females, respectively. For ages $45-64$, TUS-CPS has net relative increases of $2.5 \%(95 \%$ $\mathrm{CI}=-0.8-5.8 \%)$ for males and $3.1 \%(95 \% \mathrm{CI}=0.0-6.5 \%)$ for females, while NHIS shows a net relative increase of $8.1 \%(95 \% \mathrm{CI}=1.1-14.9 \%)$ for males but a net relative decrease of $6.9 \%$ (95\% CI $=0.4-13.1 \%$ ) for females. For ages 65 and above, TUS-CPS shows net relative increases of $8.2 \%(95 \% \mathrm{CI}=2.8-14.4 \%)$ for males and $0.8 \%(95 \% \mathrm{CI}=-4.1-6.2 \%)$ for females, compared to $5.2 \%(95 \% \mathrm{CI}=-6.6-16.1 \%)$ male and $5.2 \%(95 \% \mathrm{CI}=-7.0-17.0 \%)$ female net relative increases from NHIS.

For the 18-24 and 25-44 age groups, the No-NVP SimSmoke projected overall and the converted annual relative reduction by 2018 are outside the $95 \%$ CIs of relative changes from both TUS-CPS and NHIS for both genders. However, for the 45-64 and 65+ age groups, the No-NVP SimSmoke projected overall and annual relative changes are generally within the $95 \%$ CIs of relative changes from both TUS-CPS and NHIS for both genders. Thus, only those below age 45 show clear differences between the surveys and No-NVP SimSmoke projected trend.

\subsection{Impact of Policies in the Post-NVP Period}

Since the estimates of NVP-related impacts on smoking depend on the ability to control for policy changes from 2012 to 2018, we conducted a sensitivity analysis of the impact on SimSmoke projections from 2012 to 2018 by applying changes in policies shown in Table 4. The relative reductions in smoking prevalence from 2012 to 2018 increases with the magnitude of policy impact, and consequently the total NVP impact, i.e., their difference from actual smoking prevalence, increases with the magnitude of policy impact. Applying upper and lower bounds for each policy's effects [6], the relative reduction in adult smoking prevalence with all policies implemented ranges from $10.8 \%$ to $13.6 \%$ for males and from $11.4 \%$ to $14.2 \%$ for females, of which $0.34 \%$ were attributed to price, $0.34-0.35 \%$ to cessation treatment, $0.55-0.60 \%$ to smoke-free air laws, and $0.07-0.09 \%$ to mass media campaigns. The absolute reduction in SimSmoke smoking prevalence projections due to policy changes from 2012 to 2018 is about $1.4 \%$, representing a relatively small impact. Compared to the implied NVP impact on male smoking prevalence from TUS-CPS $(9.7 \%)$, the variation in impact is one-seventh (i.e., $1.4 \% / 9.7 \%$, where $9.7 \%$ is the difference between the SimSmoke projection and TUS-CPS estimate).

\subsection{Long-Term Impact of NVP Use during the Period 2012-2018 on Future Smoking-Attributable Deaths}

Table 5 shows the smoking-attributable deaths in total and deaths averted over the time period 2012-2052 based on the implied net NVP-related reductions in the period 2012-2018. Because only the SimSmoke projections for those below ages 45 are outside the $95 \%$ CIs of prevalence from the surveys, we estimated SADs averted excluding those ages 45 and above. Applying the TUS-CPS adjustment, 273,632 (225,991-317,096) male and 108,319 $(91,801-$ $122,168)$ female SADs are averted, yielding a total of 381,952 $(317,792-439,264)$ averted deaths. Applying the NHIS adjustment, 291,053 (203,156-381,133) male and 74,269 $(39,186-110,085)$ female SADs are averted, a total of 365,322 $(242,342-491,218)$ averted deaths. 
Table 4. Marginal sensitivity analysis of smoking prevalence to the policy changes in the period 2012-2018 as a result of their effect sizes, ages 18 and above.

\begin{tabular}{|c|c|c|c|c|c|c|c|c|c|}
\hline $\begin{array}{c}\text { Scenario } \\
*\end{array}$ & $\underset{* *}{\text { Range }}$ & 2012 & 2018 & $\begin{array}{l}\text { Relative Reduction in } \\
\text { the Period 2012-2018 }\end{array}$ & $\begin{array}{c}\text { Difference } \\
\text { from No Policy }\end{array}$ & 2012 & 2018 & $\begin{array}{l}\text { Relative Reduction in } \\
\text { the Period 2012-2018 }\end{array}$ & $\begin{array}{c}\text { Difference } \\
\text { from No Policy }\end{array}$ \\
\hline & \multicolumn{5}{|c|}{ Male Smoking prevalence } & \multicolumn{4}{|c|}{ Female Smoking Prevalence } \\
\hline No policy change & - & $17.3 \%$ & $15.7 \%$ & $9.1 \%$ & - & $13.5 \%$ & $12.2 \%$ & $9.7 \%$ & - \\
\hline \multirow{3}{*}{ Price alone } & $0 \%$ & $17.3 \%$ & $15.6 \%$ & $10.1 \%$ & $1.0 \%$ & $13.5 \%$ & $12.1 \%$ & $10.7 \%$ & $1.0 \%$ \\
\hline & $-25 \%$ & $17.3 \%$ & $15.6 \%$ & $9.8 \%$ & $0.7 \%$ & $13.5 \%$ & $12.1 \%$ & $10.4 \%$ & $0.7 \%$ \\
\hline & $+25 \%$ & $17.3 \%$ & $15.5 \%$ & $10.5 \%$ & $1.4 \%$ & $13.5 \%$ & $12.0 \%$ & $11.1 \%$ & $1.4 \%$ \\
\hline \multirow{2}{*}{$\begin{array}{l}\text { Smoke-free air laws } \\
\text { alone }\end{array}$} & $-50 \%$ & $17.3 \%$ & $15.7 \%$ & $9.4 \%$ & $0.3 \%$ & $13.5 \%$ & $12.2 \%$ & $10.0 \%$ & $0.3 \%$ \\
\hline & $+50 \%$ & $17.3 \%$ & $15.5 \%$ & $10.6 \%$ & $1.5 \%$ & $13.5 \%$ & $12.0 \%$ & $11.2 \%$ & $1.5 \%$ \\
\hline \multirow{3}{*}{$\begin{array}{c}\text { Mass media } \\
\text { campaigns alone }\end{array}$} & $0 \%$ & $17.3 \%$ & $15.7 \%$ & $9.2 \%$ & $0.1 \%$ & $13.5 \%$ & $12.2 \%$ & $9.8 \%$ & $0.1 \%$ \\
\hline & $-50 \%$ & $17.3 \%$ & $15.7 \%$ & $9.1 \%$ & $0.0 \%$ & $13.5 \%$ & $12.2 \%$ & $9.7 \%$ & $0.0 \%$ \\
\hline & $+50 \%$ & $17.3 \%$ & $15.7 \%$ & $9.3 \%$ & $0.2 \%$ & $13.5 \%$ & $12.2 \%$ & $9.9 \%$ & $0.2 \%$ \\
\hline \multirow{2}{*}{$\begin{array}{c}\text { Cessation treatment } \\
\text { alone }\end{array}$} & $0 \%$ & $17.3 \%$ & $15.6 \%$ & $9.7 \%$ & $0.6 \%$ & $13.5 \%$ & $12.1 \%$ & $10.3 \%$ & $0.6 \%$ \\
\hline & $+50 \%$ & $17.3 \%$ & $15.6 \%$ & $10.0 \%$ & $1.0 \%$ & $13.5 \%$ & $12.1 \%$ & $10.7 \%$ & $1.0 \%$ \\
\hline \multirow{3}{*}{ All above policies } & $0 \%$ & $17.3 \%$ & $15.2 \%$ & $12.2 \%$ & $3.1 \%$ & $13.5 \%$ & $11.8 \%$ & $12.8 \%$ & $3.2 \%$ \\
\hline & $-25 \% /-50 \%$ & $17.3 \%$ & $15.4 \%$ & $10.8 \%$ & $1.7 \%$ & $13.5 \%$ & $12.0 \%$ & $11.4 \%$ & $1.7 \%$ \\
\hline & $+25 \% /+50 \%$ & $17.3 \%$ & $15.0 \%$ & $13.6 \%$ & $4.5 \%$ & $13.5 \%$ & $11.6 \%$ & $14.2 \%$ & $4.6 \%$ \\
\hline
\end{tabular}

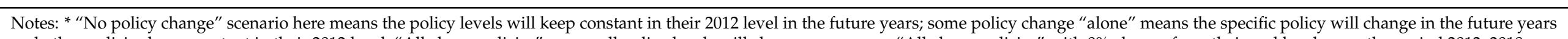

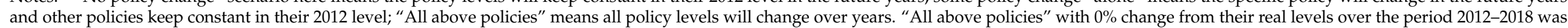
used in the main analysis to reflect the real world. ** Ranges are based on policy effect size variations from Levy et al. 2018 , with a range of $+/-25 \%$ for taxes and $+/-50 \%$ for all other policies [6]. 
Table 5. Projected smoking-attributable deaths and lives saved, unadjusted US SimSmoke compared to TUS-CPS NVPadjusted and NHIS NVP-adjusted US SimSmoke (for ages before 45), by gender, 2012-2052.

\begin{tabular}{|c|c|c|c|c|c|c|}
\hline & Adjustment & 2012 & 2018 & 2052 & 2012-2018 & 2012-2052 \\
\hline \multicolumn{7}{|c|}{ MALE } \\
\hline \multirow{5}{*}{$\begin{array}{l}\text { Smoking- } \\
\text { Attributable } \\
\text { Deaths }\end{array}$} & None & 193,271 & 190,629 & 109,884 & $1,347,094$ & $6,681,664$ \\
\hline & TUS-CPS & 193,271 & 189,629 & 97,150 & $1,343,975$ & $6,408,032$ \\
\hline & Range & - & $(189,466-189,806)$ & $(95,147-99,339)$ & $(1,343,457-1,344,539)$ & $(6,364,568-6,455,673)$ \\
\hline & NHIS & 193,271 & 189,604 & 95,862 & $1,343,896$ & $6,390,611$ \\
\hline & Range & - & $(189,258-189,942)$ & $(91,812-99,767)$ & $(1,342,788-1,344,967)$ & $(6,300,531-6,478,508)$ \\
\hline \multirow{4}{*}{$\begin{array}{l}\text { Deaths } \\
\text { Averted }\end{array}$} & TUS-CPS & - & 1000 & 12,734 & 3119 & 273,632 \\
\hline & Range & - & $(822-1163)$ & $(10,545-14,737)$ & $(2555-3637)$ & $(225,991-317,096)$ \\
\hline & NHIS & - & 1025 & 14,022 & 3198 & 291,053 \\
\hline & Range & - & $(686-1371)$ & $(10,117-18,072)$ & $(2127-4306)$ & $(203,156-381,133)$ \\
\hline \multicolumn{7}{|c|}{ FEMALE } \\
\hline \multirow{5}{*}{$\begin{array}{l}\text { Smoking- } \\
\text { Attributable } \\
\text { Deaths }\end{array}$} & None & 103,939 & 104,084 & 80,241 & 729,860 & $4,038,753$ \\
\hline & TUS-CPS & 103,939 & 103,950 & 72,912 & 729,507 & $3,930,434$ \\
\hline & Range & - & $(103,933-103,971)$ & $(71,942-74,034)$ & $(729,462-729,563)$ & $(3,916,586-3,946,952)$ \\
\hline & NHIS & 103,939 & 104,004 & 74,777 & 729,649 & $3,964,485$ \\
\hline & Range & - & $(103,959-104,047)$ & $(72,342-77,151)$ & $(729,530-729,763)$ & $(3,928,668-3,999,568)$ \\
\hline \multirow{4}{*}{$\begin{array}{l}\text { Deaths } \\
\text { Averted }\end{array}$} & TUS-CPS & - & 134 & 7330 & 353 & 108,319 \\
\hline & Range & - & $(113-151)$ & $(6207-8299)$ & $(298-399)$ & $(91,801-122,168)$ \\
\hline & NHIS & - & 80 & 5465 & 211 & 74,269 \\
\hline & Range & - & $(37-125)$ & $(3091-7899)$ & $(97-330)$ & $(39,186-110,085)$ \\
\hline \multicolumn{7}{|c|}{ BOTH } \\
\hline \multirow{5}{*}{$\begin{array}{l}\text { Smoking- } \\
\text { Attributable } \\
\text { Deaths }\end{array}$} & None & 297,211 & 294,713 & 190,126 & $2,076,954$ & $10,720,417$ \\
\hline & TUS-CPS & 297,211 & 293,579 & 170,062 & $2,073,482$ & $10,338,466$ \\
\hline & Range & - & $(293,400-293,777)$ & $(167,089-173,374)$ & $(2,072,919-2,074,101)$ & $\begin{array}{l}(10,281,154- \\
10,402,625)\end{array}$ \\
\hline & NHIS & 297,211 & 293,607 & 170,639 & $2,073,545$ & $10,355,096$ \\
\hline & Range & - & $(293,217-293,989)$ & $(164,154-176,918)$ & $(2,072,318-2,074,730)$ & $\begin{array}{l}(10,229,199- \\
10,478,075)\end{array}$ \\
\hline \multirow{4}{*}{$\begin{array}{l}\text { Deaths } \\
\text { Averted }\end{array}$} & TUS-CPS & - & 1134 & 20,064 & 3472 & 381,952 \\
\hline & Range & - & (935-1313) & $(16,752-23,036)$ & $(2853-4035)$ & $(317,792-439,264)$ \\
\hline & NHIS & - & 1106 & 19,487 & 3409 & 365,322 \\
\hline & Range & - & $(724-1496)$ & $(13,208-25,972)$ & $(2224-4636)$ & $(242,342-491,218)$ \\
\hline
\end{tabular}

Notes: 1. TUS-CPS = Tobacco Use Supplement of Current Population Survey that measures those who have smoked 100 cigarettes or more in their lifetime and currently smoke daily or someday. 2. NHIS = National Health Interview Survey that measures those who have smoked 100 cigarettes or more in their lifetime and now smoke every day or some days. 3. No adjustment refers to SimSmoke projections without NVP adjustment in the period 2012-2018 and TUS-CPS and NHIS adjustments refer to the SimSmoke projections with NVP adjustment in the period 2012-2018 using the best estimated reduction in smoking prevalence reflected from the TUS-CPS and NHIS surveys. 4. Range refers to the implementation of TUS-CPS and NHIS adjustments using the annual relative difference in the period 2012-2018 derived from the lower and upper bound of the 95\% confidence intervals from the surveys in 2018.

As sensitivity analysis, we included deaths for ages 45 and above along with those at younger ages. As a result of findings that NVP use may increase smoking for some older 
age groups, the number of averted deaths fell slightly to $367,477(158,716-559,060)$ using TUS-CPS and 355,549 $(-52,783-775,526)$ using NHIS.

\section{Discussion}

Since stable and reliable estimates of vaping and smoking transitions are difficult to obtain, we applied an indirect method for estimating the effect of NVP use on smoking prevalence and related SADs. Over the period 2012-2018, the implied NVP-related reductions in smoking prevalence were estimated at $10-11 \%$ for male and female adults ages 18 and above, with reductions ranging from 43 to $53 \%$ for ages $18-24$ and 11 to $20 \%$ for ages $25-$ 44. The results for young adults are broadly consistent with other modeling studies [69,70], and empirical studies that show higher NVP use in this age group $[62,64,65,71,72]$ and related reductions in smoking prevalence $[19,23,26,73-77]$. At older ages, the estimates often implied NVP-related increases in smoking (e.g., through reduced cessation or increased relapse [28,29]), but SimSmoke estimates were generally within CIs of survey estimates thus suggesting no differences. When confining the implied NVP impact to ages $18-44$, the NVP-related reductions increased to $17-20 \%$ for males and $12-15 \%$ for females.

Our findings for all US adults are similar to those from the England SimSmoke model that applied the same methodology [78]. We obtained reductions of $14-20 \%$ for males and 13-20\% for females from 2012 to 2018. However, unlike the US, the effects for England were more evenly distributed across age groups. England, like the US, has less strict NVP regulations than most other countries. However, England has been regulating NVPs longer and with a broader range of policies (e.g., regarding advertising and product content), and has also begun recommending vaping to help smokers who have not otherwise been successful to quit $[79,80]$. Additionally, England has less NVP use among youth than the US, which may be due to lower nicotine limits set on products such as JUUL in comparison to the US [81-84].

Using the US model, we estimated the implied impact of the 2012-2018 NVP-related reductions in smoking prevalence on SADs. For adults ages 18 and above, SimSmoke projected close to 0.4 million SADs averted between 2012 and 2052 using both the TUSCPS-adjusted and NHIS-adjusted NVP impacts. We note that these reductions increase over time, because much of the effect of NVPs is for those at younger ages and deaths attributable to smoking occurring largely at later ages. Some of the reduction in SADs from reduced smoking would be offset by NVP-attributable deaths, but the mortality risks of NVP use, although uncertain, appear to be lower than for smokers $[26,80,85]$. Our estimates are based on NVP-related reductions in smoking prevalence from 2012 to 2018 but further reductions could occur after 2018.

Our results are subject to limitations. The impact of NVPs is inferred based on a model that controls for past trends in smoking prevalence and the impact of past and newly implemented tobacco control policies but does not explicitly incorporate the impact of NVP use. This method implicitly assumes that other than past and newly cigaretteoriented policies, vaping is the only factor that would have influenced smoking prevalence during the post-vaping period. However, the inferred impact of NVPs may be due to other factors not incorporated into our model, such as changes in attitudes toward cigarette smoking or tobacco control policies not explicitly considered. For example, Food and Drug Administration regulatory efforts [86], newly imposed advertising restrictions in 2018 [87], smoke-free public housing requirements [88] and national media campaigns such as the "Real Cost" campaign [89-91] may not have been fully captured by the model.

A second limitation is that the implied NVP impacts rely on the validity of the SimSmoke model. SimSmoke has been validated for the US [3,7,33] and many countries [92-104], and the US version of SimSmoke applied here was validated against the TUS-CPS and NHIS for the pre-NVP years 1993-2012. Our indirect method also implicitly assumes that the effects of cigarette-oriented policies are the same in the pre- and post-NVP period. However, the effects of policies targeting cigarettes may be altered by the availability of NVPs. While NVPs may blunt the impact of some cigarette-oriented policies (e.g., use of NVPs in areas that are 
smoke-free, but not vape-free) [105], NVPs may instead enhance policy impacts, because smokers may substitute NVPs for cigarettes in response to stricter cigarette-oriented policies. Indeed, demand studies [106-109] indicate that NVPs are a substitute for cigarettes, and cessation studies $[17-20,110,111]$ indicate that NVPs are often used by those who have had limited success with traditional cessation treatments. However, any policy-enhancing effect of cigarette-oriented policies due to NVPs should be included as a benefit of NVP and thus incorporated in our calculations.

Another limitation of the model is that the NVP-attributable impacts depend on the accuracy of survey estimates, which varied considerably in terms of levels and trends between TUS-CPS and NHIS. Further study is needed to explain the variation in smoking prevalence estimates between the NHIS and TUS-CPS.

The projected survey trends may depend on how the post-NVP period is defined. While relative reductions of $10 \%-11 \%$ were observed during the period 2012-2018, shifting to 2011 or 2013 as initial NVP years yielded similar reductions of $12-16 \%$ or $11-14 \%$, respectively. We note, however, that model validation was impacted by the pre-NVP period considered.

Finally, our analysis only considered potential impacts of NVPs on smoking. A complete public health assessment would require consideration of the impact of NVP use on health outcomes [30]. If NVPs increase mortality risk, then the increased deaths due to NVP use would reduce the number of total deaths averted. NVP use would improve public health to the extent that they replace smoking by those who would have otherwise initiated cigarette use or who would not have otherwise quit smoking, and negatively impact public health to the extent that it acts as a gateway to smoking or is used as a substitute for smoking cessation. In particular, policies may be needed to reduce NVP use among youth if NVPs act as a gateway to smoking.

\section{Conclusions}

Our model results imply that historical and ongoing tobacco control policies in the US cannot fully explain the accelerated reductions in smoking prevalence in the time period when NVP use became more prevalent. These reductions were found mainly among those at younger ages who are more likely to use NVPs. While our results suggest an important role of NVPs in reducing smoking prevalence, further research is needed to explicitly evaluate net changes in smoking initiation and cessation associated with NVP use, and how these changes could be influenced by future cigarette-oriented and NVP-oriented policies.

Author Contributions: Conceptualization, D.T.L., R.M., J.T., N.T., Z.Y., L.M.S.-R., Y.L. and J.J.; Methodology, D.T.L.; Programming Software, Z.Y., L.M.S.-R. and Y.L.; Validation, D.T.L., Z.Y., L.M.S.R. and Y.L.; Formal Analysis, D.T.L., Z.Y., L.M.S.-R. and Y.L.; Investigation, D.T.L.; Resources, D.T.L. and R.M.; Data Curation, Z.Y., L.M.S.-R. and Y.L.; Writing-Original Draft Preparation, D.T.L., S.S. and Z.Y.; Writing-Review and Editing, D.T.L., R.M., J.T., Z.Y., L.M.S.-R., Y.L., S.S., N.T. and J.J.; Supervision, D.T.L.; Project Administration, D.T.L., N.T.; Funding Acquisition, D.T.L. and R.M. All authors have read and agreed to the published version of the manuscript.

Funding: This project was funded through National Cancer Institute (NCI) through grant P01CA200512 and through NCI and Food and Drug Administration (FDA) grant U54-CA229974. The opinions expressed in this article are the authors' own and do not reflect the views of the National Institutes of Health, the Department of Health and Human Services, or the United States government.

Institutional Review Board Statement: There was no direct human involvement. All data were publicly available.

Informed Consent Statement: There was no direct human involvement in gathering data. All data were publicly available.

Data Availability Statement: Data and the model will be provided upon request.

Acknowledgments: We would also like to thank Stephanie Land and Alex Liber for their helpful comments. 
Conflicts of Interest: All authors declare that they have no competing interest.

\section{References}

1. U.S. Department of Health and Human Services. The Health Consequences of Smoking—50 Years of Progress: A Report of the Surgeon General; Centers for Disease Control and Prevention, U.S. Department of Health and Human Services, National Center for Chronic Disease Prevention and Health Promotion, Office on Smoking and Health, Editor: Atlanta, GA, USA, 2014.

2. Holford, T.R.; Meza, R.; Warner, K.E.; Meernik, C.; Jeon, J.; Moolgavkar, S.H.; Levy, D.T. Tobacco control and the reduction in smoking-related premature deaths in the United States, 1964-2012. JAMA 2014, 311, 164-171. [CrossRef]

3. Levy, D.T.; Meza, R.; Zhang, Y.; Holford, T.R. Gauging the Effect of U.S. Tobacco Control Policies from 1965 through 2014 Using SimSmoke. Am. J. Prev. Med. 2016, 50, 535-542. [CrossRef] [PubMed]

4. Warner, K.E. Tobacco control policies and their impacts. Past, present, and future. Ann. Am. Thorac. Soc. 2014, 11, 227-230. [CrossRef] [PubMed]

5. Levy, D.T.; Meza, R.; Zhang, Y.; Holford, T.R. Impact of tobacco control on adult per capita cigarette consumption in the United States. Am. J. Public Health 2014, 104, 83-89.

6. Levy, D.T.; Tam, J.; Kuo, C.; Fong, G.T.; Chaloupka, F. The Impact of Implementing Tobacco Control Policies: The 2017 Tobacco Control Policy Scorecard. J. Public Health Manag. Pract. 2018, 24, 448-457. [CrossRef]

7. Levy, D.T.; Yuan, Z.; Li, Y. The US SimSmoke tobacco control policy model of smokeless tobacco and cigarette use. BMC Public Health 2018, 18, 696. [CrossRef] [PubMed]

8. Levy, D.T.; Yuan, Z.; Li, Y. Modeling the Effects of E-cigarettes on Smoking Behavior: Implications for Future Adult Smoking Prevalence. Epidemiology 2016, 27, 819-826.

9. Vugrin, E.D.; Rostron, B.L.; Verzi, S.J.; Brodsky, N.S.; Brown, T.J.; Choiniere, C.J.; Coleman, B.N.; Paredes, A.; Apelberg, B.J. Modeling the potential effects of new tobacco products and policies: A dynamic population model for multiple product use and harm. PLoS ONE 2015, 10, e0121008. [CrossRef] [PubMed]

10. Mendez, D.; Tam, J.; Giovino, G.A.; Tsodikov, A.; Warner, K.E. Has Smoking Cessation Increased? An Examination of the US Adult Smoking Cessation Rate 1990-2014. Nicotine Tob. Res. 2017, 19, 1418-1424. [PubMed]

11. Tam, J.; Levy, D.T.; Jeon, J.; Clarke, J.; Gilkeson, S.; Hall, T.; Feuer, E.J.; Holford, T.R.; Meza, R. Projecting the effects of tobacco control policies in the USA through microsimulation: A study protocol. BMJ Open 2018, 8, e019169. [CrossRef] [PubMed]

12. Gravely, S.; Fong, G.T.; Cummings, K.M.; Yan, M.; Quah, A.C.; Borland, R.; Yong, H.H.; Hitchman, S.C.; McNeill, A.; Hammond, D.; et al. Awareness, trial, and current use of electronic cigarettes in 10 countries: Findings from the ITC project. Int. J. Environ. Res. Public Health 2014, 11, 11691-11704. [CrossRef]

13. Yong, H.H.; Hitchman, S.C.; Cummings, K.M.; Borland, R.; Gravely, S.M.L.; McNeill, A.; Fong, G.T. Does the Regulatory Environment for E-Cigarettes Influence the Effectiveness of E-Cigarettes for Smoking Cessation?: Longitudinal Findings From the ITC Four Country Survey. Nicotine Tob. Res. 2017, 19, 1268-1276. [CrossRef] [PubMed]

14. Farsalinos, K.E.; Spyrou, A.; Tsimopoulou, K.; Stefopoulos, C.; Romagna, G.; Voudris, V. Nicotine absorption from electronic cigarette use: Comparison between first and new-generation devices. Sci. Rep. 2014, 4, 4133. [CrossRef] [PubMed]

15. Wagener, T.L.; Floyd, E.L.; Stepanov, I.; Driskill, L.M.; Frank, S.G.; Meier, E.; Leavens, E.L.; Tackett, A.P.; Molina, N.; Queimado, L. Have combustible cigarettes met their match? The nicotine delivery profiles and harmful constituent exposures of secondgeneration and third-generation electronic cigarette users. Tob. Control. 2016, 26, e23-e28. [CrossRef] [PubMed]

16. Glasser, A.M.; Collins, L.; Pearson, J.L.; Abudayyeh, H.; Niaura, R.S.; Abrams, D.B.; Villanti, A.C. Overview of Electronic Nicotine Delivery Systems: A Systematic Review. Am. J. Prev. Med. 2017, 52, e33-e66. [CrossRef] [PubMed]

17. Beard, E.; West, R.; Michie, S.; Brown, J. Association between electronic cigarette use and changes in quit attempts, success of quit attempts, use of smoking cessation pharmacotherapy, and use of stop smoking services in England: Time series analysis of population trends. BMJ 2016, 354, i4645. [CrossRef] [PubMed]

18. Caraballo, R.S.; Shafer, P.R.; Patel, D.; Davis, K.C.; McAfee, T.A. Quit Methods Used by US Adult Cigarette Smokers, $2014-2016$. Prev. Chronic Dis. 2017, 14, E32. [CrossRef]

19. Levy, D.T.; Yuan, Z.; Luo, Y.; Abrams, D.B. The Relationship of E-Cigarette Use to Cigarette Quit Attempts and Cessation: Insights From a Large, Nationally Representative U.S. Survey. Nicotine Tob. Res. 2017, 20, 931-939. [CrossRef] [PubMed]

20. Patel, D.; Davis, K.C.; Cox, S.; Bradfield, B.; King, B.A.; Shafer, P.; Caraballo, R.; Bunnell, R. Reasons for current E-cigarette use among U.S. adults. Prev. Med. 2016, 93, 14-20. [CrossRef]

21. Hajek, P.; Phillips-Waller, A.; Przulj, D.; Pesola, F.; Myers Smith, K.; Bisal, N.; Li, J.; Parrott, S.; Sasieni, P.; Dawkins, L.; et al. A Randomized Trial of E-Cigarettes versus Nicotine-Replacement Therapy. N. Engl. J. Med. 2019, 380, 629-637. [CrossRef]

22. Levy, D.T.; Borland, R.; Villanti, A.C.; Niaura, R.; Yuan, Z.; Zhang, Y.; Meza, R.; Holford, T.R.; Fong, G.T.; Cummings, K.M.; et al. The Application of a Decision-Theoretic Model to Estimate the Public Health Impact of Vaporized Nicotine Product Initiation in the United States. Nicotine Tob. Res. 2017, 19, 149-159. [CrossRef]

23. Levy, D.T.; Warner, K.E.; Cummings, K.M.; Hammond, D.; Kuo, C.; Fong, G.T.; Thrasher, J.F.; Goniewicz, M.L.; Borland, R. Examining the relationship of vaping to smoking initiation among US youth and young adults: A reality check. Tob. Control. 2019, 28, 629-635. [CrossRef] [PubMed]

24. Foxon, F.; Selya, A.S. Electronic cigarettes, nicotine use trends and use initiation ages among US adolescents from 1999 to 2018. Addiction 2020, 115, 2369-2378. [CrossRef] [PubMed] 
25. Soneji, S.; Barrington-Trimis, J.L.; Wills, T.A.; Leventhal, A.M.; Unger, J.B.; Gibson, L.A.; Yang, J.; Primack, B.A.; Andrews, J.A.; Miech, R.A.; et al. Association Between Initial Use of e-Cigarettes and Subsequent Cigarette Smoking Among Adolescents and Young Adults: A Systematic Review and Meta-analysis. JAMA Pediatr. 2017, 171, 788-797. [CrossRef]

26. Watkins, S.L.; Glantz, S.A.; Chaffee, B.W. Association of Noncigarette Tobacco Product Use With Future Cigarette Smoking Among Youth in the Population Assessment of Tobacco and Health (PATH) Study, 2013-2015. JAMA Pediatr. 2018, 172, 181-187. [CrossRef] [PubMed]

27. National Academies of Sciences, Engineering, and Medicine; Health and Medicine Division; Board on Population Health and Public Health Practice; Committee on the Review of the Health Effects of Electronic Nicotine Delivery Systems; Eaton, D.L.; Kwan, Y.L.; Stratton, K. Public Health Consequences of E-Cigarettes; The National Acadamies Press: Washington, DC, USA, 2018.

28. Miller, C.R.; Smith, D.M.; Goniewicz, M.L. Changes in Nicotine Product Use among Dual Users of Tobacco and Electronic Cigarettes: Findings from the Population Assessment of Tobacco and Health (PATH) Study, 2013-2015. Subst. Use Misuse 2020, 55, 909-913. [CrossRef] [PubMed]

29. Azagba, S.; Qeadan, F.; Shan, L.; Latham, K.; Wolfson, M. E-Cigarette Use and Transition in Adult Smoking Frequency: A Longitudinal Study. Am. J. Prev. Med. 2020, 59, 367-376. [CrossRef]

30. Dai, H.; Leventhal, A.M. Association of electronic cigarette vaping and subsequent smoking relapse among former smokers. Drug Alcohol Depend. 2019, 199, 10-17. [CrossRef]

31. Levy, D.T.; Cummings, K.M.; Villanti, A.C.; Niaura, R.; Abrams, D.B.; Fong, G.T.; Borland, R. A framework for evaluating the public health impact of e-cigarettes and other vaporized nicotine products. Addiction 2017, 112, 8-17. [CrossRef] [PubMed]

32. Abrams, D.B. Promise and peril of e-cigarettes: Can disruptive technology make cigarettes obsolete? JAMA 2014, 311, 135-136. [CrossRef]

33. Stimson, G.V.; Thom, B.; Costall, P. Disruptive innovations: The rise of the electronic cigarette. Int. J. Drug Policy 2014, 25, 653-655. [CrossRef] [PubMed]

34. Levy, D.T.; Nikolayev, L.; Mumford, E. Recent trends in smoking and the role of public policies: Results from the SimSmoke tobacco control policy simulation model. Addiction 2005, 100, 1526-1536. [CrossRef] [PubMed]

35. Levy, D.T.; Bauer, J.E.; Lee, H.R. Simulation modeling and tobacco control: Creating more robust public health policies. Am. J. Public Health 2006, 96, 494-498. [CrossRef] [PubMed]

36. Levy, D.T.; Nikolayev, N.; Mumford, E.A. The Healthy People 2010 Smoking Prevalence and Tobacco Control Objectives: Results from the SimSmoke Tobacco Control Policy Simulation Model. Cancer Causes Control. 2005, 16, 359-371. [CrossRef] [PubMed]

37. U.S. Bureau of the Census. Population by Age and State. 1993. 2 January 2017. Available online: http://www.census.gov/ popest/data/intercensal/state/files/ST-EST00INT-AGESEX.csv (accessed on 15 June 2020).

38. U.S. Census Bureau, Current Population Survey. US Population by Age and Gender. 2019. Available online: www.census.gov (accessed on 15 June 2020).

39. U.S. Bureau of the Census. Projected Net International Migration by Age, Sex, Race, and Hispanic Origin: 2014 to 2060 , US Census Bureau. 2016. Available online: https://www.census.gov/population/projections/data/national/2014/downloadablefiles.html (accessed on 15 June 2020).

40. Jeon, J.; Holford, T.R.; Levy, D.T.; Feuer, E.J.; Cao, P.; Tam, J.; Clarke, L.; Clarke, J.; Kong, C.Y.; Meza, R. Smoking and Lung Cancer Mortality in the United States from 2015 to 2065: A Comparative Modeling Approach. Ann. Intern. Med. 2018, 169, 684-693. [CrossRef] [PubMed]

41. US Department of Commerce, Census Bureau. National Cancer Institute and Centers for Disease Control and Prevention Cosponsored Tobacco Use Supplement to the Current Population Survey (1992-1993). 1998. Available online: http: / / appliedresearch. cancer.gov/tus-cps/ (accessed on 12 March 2021).

42. Rosenberg, M.A.; Feuer, E.J.; Yu, B.; Sun, J.; Henley, S.J.; Shanks, T.G.; Anderson, C.M.; McMahon, P.M.; Thun, M.J.; Burns, D.M. Chapter 3: Cohort life tables by smoking status, removing lung cancer as a cause of death. Risk Anal. 2012, 32 (Suppl. S1), S25-S38. [CrossRef] [PubMed]

43. Burns, D.; Garfinkel, L.; Samet, J. (Eds.) Changes in Cigarette-Related Disease Risks and Their Implication for Prevention and Control; Smoking and Tobacco Control Monograph 8; National Institutes of Health, National Cancer Institute: Bethesda, MD, USA, 1997.

44. Burns, D.; Shanks, T.; Choi, W.; Thun, M.; Heath, C.J.; Garfinkel, L. The American Cancer Society Cancer Prevention Study I: 12-year followup of 1 million men and women. In Changes in Cigarette-Related Disease Risks and Their Implication for Prevention and Control, Smoking and Tobacco Control. Monograph 8; National Cancer Institute, National Institutes of Health: Bethesda, MD, USA, 1997; pp. 113-304.

45. Carter, B.D.; Abnet, C.C.; Feskanich, D.; Freedman, N.D.; Hartge, P.; Lewis, C.E.; Ockene, J.K.; Prentice, R.L.; Speizer, F.E.; Thun, M.J.; et al. Smoking and mortality-beyond established causes. N. Engl. J. Med. 2015, 372, 631-640. [CrossRef]

46. Kenfield, S.A.; Stampfer, M.J.; Rosner, B.A.; Colditz, G.A. Smoking and smoking cessation in relation to mortality in women. JAMA 2008, 299, 2037-2047. [CrossRef]

47. Peto, R.; Darby, S.; Deo, H.; Silcocks, P.; Whitley, E.; Doll, R. Smoking, smoking cessation, and lung cancer in the UK since 1950: Combination of national statistics with two case-control studies. BMJ 2000, 321, 323-329. [CrossRef] 
48. Burns, D.; Anderson, C.; Johnson, M.; Major, J.; Biener, L.; Vaughn, J.; Shanks, T. Cessation and Cessation Measures among Daily Adult Smokers: National-and State-Specific Data, in Population-Based Smoking Cessation: A Conference on What Works to Influence Smoking in the General Population. Smoking and Tobacco Control. Monograph No. 12; N.C. Institute, Ed.; National Cancer Institute, National Institutes of Health: Bethesda, MD, USA, 2000; pp. 113-304.

49. Gilpin, E.A.; Pierce, J.P.; Farkas, A.J. Duration of smoking abstinence and success in quitting. J. Natl. Cancer Inst. 1997, 89, 572-576. [CrossRef] [PubMed]

50. Hughes, J.R.; Callas, P.W. Errors in interpreting abstinence curves in studies of smoking cessation. Nicotine Tob. Res. 2006, 8, 7-12. [CrossRef] [PubMed]

51. Hughes, J.R.; Peters, E.N.; Naud, S. Relapse to Smoking after 1 Year of Abstinence: A Meta-analysis. Addict. Behav. 2008, 33, 1516-1520. [CrossRef]

52. Levy, D.T.; Cummings, K.M.; Hyland, A. Increasing taxes as a strategy to reduce cigarette use and deaths: Results of a simulation model. Prev. Med. 2000, 31, 279-286. [CrossRef] [PubMed]

53. Orzechowski, W.; Walker, R. The Tax Burden on Tobacco Volume 52, 1970-2018; Orzechowski and Walker: Arlington, VA, USA, 2018.

54. U.S. Bureau of Labor Statistics. Consumer Price Index for All Urban. Consumers (CPI-U). $2020 \backslash$ [cited 2020 July 12]. Available online: https: / / data.bls.gov/timeseries/CUSR0000SA0 (accessed on 19 July 2020).

55. Levy, D.T.; Friend, K.; Polishchuk, E. Effect of clean indoor air laws on smokers: The clean air module of the SimSmoke computer simulation model. Tob. Control. 2001, 10, 345-351. [CrossRef] [PubMed]

56. Americans for Nonsmokers Rights. Chronological Table of U.S. Population Protected by $100 \%$ Smokefree State or Local Laws. 2019 [cited 8 February 2019]. Available online: http:/ / no-smoke.org/pdf/EffectivePopulationList.pdf (accessed on 12 July 2020).

57. Friend, K.; Levy, D. Reductions in smoking prevalence and cigarette consumption associated with mass-media campaigns. Health Educ. Res. 2002, 17, 85-98. [CrossRef]

58. Campaign for Tobacco-Free Kids. History of Spending for State Tobacco Prevention Programs. 2019. [cited 8 November 2019]. Available online: https:/ / www.tobaccofreekids.org/assets/factsheets/0209.pdf (accessed on 17 July 2020).

59. Levy, D.; Graham, A.; Mabry, P.; Abrams, D.; Orleans, C.T. Modeling the Impact of Smoking Cessation Treatment Policies on Quit Rates. Am. J. Prev Med. 2010, 38, S364-S372. [CrossRef]

60. American Lung Association. Tobacco Control. Highlights. 2020 [cited 21 July 2020]. Available online: https://www.lung.org/ getmedia / fb9cdabf-7062-4e49-b86b-74754ab642eb/exchange-data-report_final_1.pdf (accessed on 17 July 2020).

61. Levy, D.T.; Friend, K.; Holder, H. Effect of policies directed at youth access to smoking: Results from the SimSmoke computer simulation model. Tob. Control. 2001, 10, 108-116. [CrossRef] [PubMed]

62. Levy, D.T.; Yuan, Z.; Li, Y.; Mays, D.; Sanchez-Romero, L.M. An Examination of the Variation in Estimates of E-Cigarette Prevalence among U.S. Adults. Int. J. Environ. Res. Public Health 2019, 16, 3164. [CrossRef]

63. Marynak, K.L.; Gammon, D.G.; King, B.A.; Loomis, B.R.; Fulmer, E.B.; Wang, T.W.; Rogers, T. National and State Trends in Sales of Cigarettes and E-Cigarettes, U.S., 2011-2015. Am. J. Prev Med. 2017, 53, 96-101. [CrossRef]

64. Bao, W.; Liu, B.; Du, Y.; Snetselaar, L.G.; Wallace, R.B. Electronic Cigarette Use Among Young, Middle-Aged, and Older Adults in the United States in 2017 and 2018. JAMA Intern. Med. 2019, 180, 313-314. [CrossRef]

65. Dai, H.; Leventhal, A.M. Prevalence of e-Cigarette Use Among Adults in the United States, 2014-2018. JAMA 2019, 322, 1824-1827. [CrossRef] [PubMed]

66. Giovino, G.A. Why joe camel is still smiling. Tob. Control. 2000, 9, 260. [CrossRef]

67. P Bao, W.; Liu, B.; Du, Y.; Snetselaar, L.G.; Wallace, R.B. Tobacco industry promotion of cigarettes and adolescent smoking. JAMA 1998, 279, 511-515.

68. Pierce, J.P.; Gilpin, E.A.; Choi, W.S. Sharing the blame: Smoking experimentation and future smoking-attributable mortality due to Joe Camel and Marlboro advertising and promotions. Tob. Control. 1999, 8, 37-44. [CrossRef] [PubMed]

69. Warner, K.E.; Mendez, D. E-cigarettes: Comparing the Possible Risks of Increasing Smoking Initiation with the Potential Benefits of Increasing Smoking Cessation. Nicotine Tob. Res. 2019, 21, 41-47. [CrossRef] [PubMed]

70. Levy, D.T.; Yuan, Z.; Li, Y.; Alberg, A.J.; Cummings, K.M. A modeling approach to gauging the effects of nicotine vaping product use on cessation from cigarettes: What do we know, what do we need to know? Addiction 2019, 114 (Suppl. S1), 86-96. [CrossRef] [PubMed]

71. Levy, D.T.; Yuan, Z.; Li, Y. The Prevalence and Characteristics of E-Cigarette Users in the U.S. Int. J. Environ. Res. Public Health 2017, 14, 1200. [CrossRef]

72. Xu, Y.; Guo, Y.; Liu, K.; Liu, Z.; Wang, X. E-Cigarette Awareness, Use, and Harm Perception among Adults: A Meta-Analysis of Observational Studies. PLoS ONE 2016, 11, e0165938. [CrossRef] [PubMed]

73. Zhu, S.H.; Zhuang, Y.L.; Wong, S.; Cummins, S.E.; Tedeschi, G.J. E-cigarette use and associated changes in population smoking cessation: Evidence from US current population surveys. BMJ 2017, 358, j3262. [CrossRef]

74. Zhuang, Y.L.; Cummins, S.E.; Sun, J.Y.; Zhu, S.H. Long-term e-cigarette use and smoking cessation: A longitudinal study with US population. Tob. Control. 2016, 25 (Suppl. S1), i90-i95. [CrossRef]

75. Beard, E.; Jackson, S.E.; West, R.; Kuipers, M.A.; Brown, J. Population-level predictors of changes in success rates of smoking quit attempts in England: A time series analysis. Addiction 2019, 115, 315-325. [CrossRef] [PubMed] 
76. Beard, E.; Jackson, S.E.; West, R.; Kuipers, M.A.G.; Brown, J. Association of prevalence of electronic cigarette use with smoking cessation and cigarette consumption in England: A time-series analysis between 2007 and 2017. Addiction 2019, 115, 961-974. [CrossRef]

77. Brown, J.; Beard, E.; Kotz, D.; Michie, S.; West, R. Real-world effectiveness of e-cigarettes when used to aid smoking cessation: A cross-sectional population study. Addiction 2014, 109, 1531-1540. [CrossRef]

78. Levy, D.T.; Sánchez-Romero, L.M.; Li, Y.; Yuan, Z.; Travis, N.; Jarvis, M.J.; Brown, J.; McNeill, A. England SimSmoke: The Impact of Nicotine Vaping on Smoking Prevalence and Smoking-Attributable Deaths in England. Addiction 2020. [CrossRef] [PubMed]

79. House of Commons Science and Technology Committee. E-Cigarettes, Seventh Report of Session 2017-2019. 2018 [cited 29 March 2020]. Available online: https://publications.parliament.uk/pa/cm201719/cmselect/cmsctech/505/505.pdf (accessed on 29 July 2020).

80. McNeill, A.; Brose, L.; Calder, R.; Bauld, L.; Robson, D. Vaping in England: An Evidence Update Including Mental Health and Pregnancy, March 2020: A Report Commissioned by Public Health England; Public Health England: London, UK, 2020.

81. Goniewicz, M.L.; Boykan, R.; Messina, C.R.; Eliscu, A.; Tolentino, J. High exposure to nicotine among adolescents who use Juul and other vape pod systems ('pods'). Tob. Control. 2019, 28, 676-677. [CrossRef] [PubMed]

82. Hammond, D.; Reid, J.L.; Rynard, V.L.; Fong, G.T.; Cummings, K.M.; McNeill, A.; Hitchman, S.; Thrasher, J.F.; Goniewicz, M.L.; Bansal-Travers, M.; et al. Prevalence of vaping and smoking among adolescents in Canada, England, and the United States: Repeat national cross sectional surveys. BMJ 2019, 365, 12219. [CrossRef] [PubMed]

83. Leavens, E.L.S.; Stevens, E.M.; Brett, E.I.; Hebert, E.T.; Villanti, A.C.; Pearson, J.L.; Wagener, T.L. JUUL electronic cigarette use patterns, other tobacco product use, and reasons for use among ever users: Results from a convenience sample. Addict. Behav. 2019, 95, 178-183. [CrossRef] [PubMed]

84. Vallone, D.M.; Cuccia, A.F.; Briggs, J.; Xiao, H.; Schillo, B.A.; Hair, E.C. Electronic Cigarette and JUUL Use among Adolescents and Young Adults. JAMA Pediatr. 2020, 174, 277-286. [CrossRef] [PubMed]

85. Nutt, D.J.; Phillips, L.D.; Balfour, D.; Curran, H.V.; Dockrell, M.; Foulds, J.; Fagerstrom, K.; Letlape, K.; Polosa, R.; Ramsey, J.; et al. E-cigarettes are less harmful than smoking. Lancet 2016, 387, 1160-1162. [CrossRef]

86. Department of Health and Human Services, Food and Drug Administration. Deeming Tobacco Products to Be Subject to the Federal Food, Drug, and Cosmetic Act, as Amended by the Family Smoking Prevention and Tobacco Control. Act; Regulations on the Sale and Distribution of Tobacco Products and Required Warning Statements for Tobacco Products; 81 FR 28973; Office of the Federal Register, National Archives and Records Administration (NARA): Washington, DC, USA, 2014.

87. Department of Health and Human Services, Food and Drug Administration. Title 21. Food and Drugs. Chapter I. Food and Drug Administration, Department of Health and Human Service Subchapter K. Tobacco Products, Part. 1140. Cigarettes,. Smokeless Tobacco, and Covered Tobacco Products, Regulations Restricting the Sale and Distribution of Cigarettes and Smokeless Tobacco to Protect. Children and Adolescents. In 21 CFR Part. 1140 [Docket No. FDA-1995-N-0259]; Dhhs, F., Ed.; Office of the Federal Register, National Archives and Records Administration (NARA): Washington, DC, USA, 2018.

88. Department of Housing and Urban Development; Instituting Smoke-free Public Housing. 24 CFR Parts 965 and 966; Office of the Federal Register, National Archives and Records Administration (NARA): Washington, DC, USA, 2016.

89. Duke, J.C.; Farrelly, M.C.; Alexander, T.N.; MacMonegle, A.J.; Zhao, X.; Allen, J.A.; Delahanty, J.C.; Rao, P.; Nonnemaker, J. Effect of a National Tobacco Public Education Campaign on Youth's Risk Perceptions and Beliefs about Smoking. Am. J. Health Promot. 2017, 32, 1248-1256. [CrossRef] [PubMed]

90. Duke, J.C.; MacMonegle, A.J.; Nonnemaker, J.M.; Farrelly, M.C.; Delahanty, J.C.; Zhao, X.; Smith, A.A.; Rao, P.; Allen, J.A. Impact of the Real Cost Media Campaign on Youth Smoking Initiation. Am. J. Prev. Med. 2019, 57, 645-651. [CrossRef] [PubMed]

91. Farrelly, M.C.; Duke, J.C.; Nonnemaker, J.; MacMonegle, A.J.; Alexander, T.N.; Zhao, X.; Delahanty, J.C.; Rao, P.; Allen, J.A. Association between the Real Cost Media Campaign and Smoking Initiation Among Youths-United States, 2014-2016. MMWR. Morb. Mortal. Wkly. Rep. 2017, 66, 47-50. [CrossRef]

92. Currie, L.M.; Blackman, K.; Clancy, L.; Levy, D.T. The effect of tobacco control policies on smoking prevalence and smokingattributable deaths in Ireland using the IrelandSS simulation model. Tob. Control. 2013, 22, e25-e32. [CrossRef] [PubMed]

93. Levy, D.; de Almeida, L.M.; Szklo, A. The Brazil SimSmoke policy simulation model: The effect of strong tobacco control policies on smoking prevalence and smoking-attributable deaths in a middle income nation. PLoS Med. 2012, 9, e1001336. [CrossRef]

94. Levy, D.; Rodriguez-Buno, R.L.; Hu, T.W.; Moran, A.E. Projections from the China SimSmoke simulation model. BMJ 2014, 348, g1134. [CrossRef]

95. Levy, D.; Benjakul, S.; Ross, H.; Ritthiphakdee, B. The Role of Tobacco Control Policies in Reducing Smoking and Deaths in a Middle Income Nation: Results from the Thailand SimSmoke Simulation Model. Tob. Control. 2008, 17, 53-59. [CrossRef] [PubMed]

96. Levy, D.T.; Blackman, K.; Currie, L.M.; Mons, U. Germany SimSmoke: The effect of tobacco control policies on future smoking prevalence and smoking-attributable deaths in Germany. Nicotine Tob. Res. 2013, 15, 465-473. [CrossRef] [PubMed]

97. Levy, D.; Cho, S.; Kim, Y.-M.; Park, S.; Suh, M.-K.; Kam, S. An Evaluation of the Impact of Tobacco Control Policies in Korea Using the SimSmoke Model: The Unknown Success Story. Am. J. Public Health 2010, 100, 1267-1273. [CrossRef]

98. Reynales-Shigematsu, L.M.; Fleischer, N.L.; Thrasher, J.F.; Zhang, Y.; Meza, R.; Cummings, K.M.; Levy, D.T. Effects of tobacco control policies on smoking prevalence and tobacco-attributable deaths in Mexico: The SimSmoke model. Rev. Panam. Salud Publica 2015, 38, 316-325. [PubMed] 
99. Maslennikova, G.Y.; Oganov, R.G.; Boytsov, S.A.; Ross, H.; Huang, A.T.; Near, A.; Kotov, A.; Berezhnova, I.; Levy, D.T. Russia SimSmoke: The long-term effects of tobacco control policies on smoking prevalence and smoking-attributable deaths in Russia. Tob. Control. 2013, 23, 484-490. [CrossRef] [PubMed]

100. Nagelhout, G.E.; Levy, D.T.; Blackman, K.; Currie, L.; Clancy, L.; Willemsen, M.C. The effect of tobacco control policies on smoking prevalence and smoking-attributable deaths. Findings from the Netherlands SimSmoke Tobacco Control Policy Simulation Model. Addiction 2012, 107, 407-416. [CrossRef] [PubMed]

101. Levy, D.T.; Currie, L.; Clancy, L. Tobacco control policy in the UK: Blueprint for the rest of Europe? Eur J. Public Health 2013, 23, 201-206. [CrossRef]

102. Levy, D.T.; Ross, H.; Kmentova, A.; Kralikova, E.; Stoklosa, M.; Blackman, K. The Effect of Tobacco Control Policies on Smoking Prevalence and Smoking Attributable Deaths in the Czech Republic. Addiction 2012, 107, 407-416. [CrossRef]

103. Near, A.M.; Blackman, K.; Currie, L.M.; Levy, D.T. Sweden SimSmoke: The effect of tobacco control policies on smoking and snus prevalence and attributable deaths. Eur. J. Public Health 2014, 24, 451-458. [CrossRef] [PubMed]

104. Levy, D.T.; Gallus, S.; Blackman, K.; Carreras, G.; La Vecchia, C.; Gorini, I. Italy SimSmoke: The effect of tobacco control policies on smoking prevalence and smoking attributable deaths in Italy. BMC Public Health 2012, 12, 709. [CrossRef] [PubMed]

105. Dunbar, Z.R.; Giovino, G.; Wei, B.; O'Connor, R.J.; Goniewicz, M.L.; Travers, M.J. Use of Electronic Cigarettes in Smoke-Free Spaces by Smokers: Results from the 2014-2015 Population Assessment on Tobacco and Health Study. Int J Environ Res Public Health 2020, 17, 978. [CrossRef]

106. Huang, J.; Gwarnicki, C.; Xu, X.; Caraballo, R.S.; Wada, R.; Chaloupka, F.J. A comprehensive examination of own- and cross-price elasticities of tobacco and nicotine replacement products in the U.S. Prev. Med. 2018, 117, 107-114. [CrossRef] [PubMed]

107. Pesko, M.F.; Huang, J.; Johnston, L.D.; Chaloupka, F.J. E-cigarette price sensitivity among middle- and high-school students: Evidence from monitoring the future. Addiction 2018, 113, 896-906. [CrossRef]

108. Zheng, Y.; Zhen, C.; Dench, D.; Nonnemaker, J.M. U.S. Demand for Tobacco Products in a System Framework. Health Econ. 2016, $26,1067-1086$.

109. Huang, J.; Tauras, J.; Chaloupka, F.J. The impact of price and tobacco control policies on the demand for electronic nicotine delivery systems. Tob. Control. 2014, 23 (Suppl. S3), iii41-iii47. [CrossRef] [PubMed]

110. Beard, E.; Brose, L.S.; Brown, J.; West, R.; McEwen, A. How are the English Stop Smoking Services responding to growth in use of electronic cigarettes? Patient Educ. Couns. 2014, 94, 276-281. [CrossRef] [PubMed]

111. Beard, E.; Brown, J.; McNeill, A.; Michie, S.; West, R. Has growth in electronic cigarette use by smokers been responsible for the decline in use of licensed nicotine products? Findings from repeated cross-sectional surveys. Thorax 2015, 70, 974-978. [CrossRef] [PubMed] 